\title{
Green cheese: Partial life cycle assessment of greenhouse gas emissions and energy intensity of integrated dairy production and bioenergy systems
}

\author{
H. A. Aguirre-Villegas, ${ }^{* 1}$ T. H. Passos-Fonseca,† D. J. Reinemann, ${ }^{*}$ L. E. Armentano, $\ddagger$ M. A. Wattiaux, $\ddagger$ \\ V. E. Cabrera, $\ddagger$ J. M. Norman,§ and R. Larson* \\ *Department of Biological Systems Engineering, \\ †Agroecology Program, \\ †Department of Dairy Science, and \\ $\S$ Department of Soil Sciences, University of Wisconsin, Madison 53706
}

\begin{abstract}
The objective of this study was to evaluate the effect of integrating dairy and bioenergy systems on land use, net energy intensity (NEI), and greenhouse gas (GHG) emissions. A reference dairy farm system representative of Wisconsin was compared with a system that produces dairy and bioenergy products. This integrated system investigates the effects at the farm level when the cow diet and manure management practices are varied. The diets evaluated were supplemented with varying amounts of dry distillers grains with solubles and soybean meal and were balanced with different types of forages. The manure-management scenarios included manure land application, which is the most common manure disposal method in Wisconsin, and manure anaerobic digestion (AD) to produce biogas. A partial life cycle assessment from cradle to farm gate was conducted, where the system boundaries were expanded to include the production of biofuels in the analysis and the environmental burdens between milk and bioenergy products were partitioned by system expansion. Milk was considered the primary product and the functional unit, with ethanol, biodiesel, and biogas considered co-products. The production of the co-products was scaled according to milk production to meet the dietary requirements of each selected dairy ration. Results indicated that land use was $1.6 \mathrm{~m}^{2}$, NEI was $3.86 \mathrm{MJ}$, and GHG emissions were $1.02 \mathrm{~kg}$ of $\mathrm{CO}_{2^{-}}$ equivalents per kilogram of fat- and protein-corrected milk (FPCM) for the reference system. Within the integrated dairy and bioenergy system, diet scenarios that maximize dry distillers grains with solubles and implement AD had the largest reduction of GHG emissions and NEI, but the greatest increase in land use compared with the reference system. Average land use ranged from 1.68 to $2.01 \mathrm{~m}^{2} / \mathrm{kg}$ of FPCM; NEI ranged
\end{abstract}

Received September 12, 2014

Accepted November 22, 2014.

${ }^{1}$ Corresponding author: aguirreville@wisc.edu from -5.62 to $-0.73 \mathrm{MJ} / \mathrm{kg}$ of FPCM; and GHG emissions ranged from 0.63 to $0.77 \mathrm{~kg}$ of $\mathrm{CO}_{2}$-equivalents/ $\mathrm{kg}$ of FPCM. The AD contributed $65 \%$ of the NEI and $77 \%$ of the GHG emission reductions.

Key words: bioenergy, greenhouse gas emission, energy intensity, life cycle assessment, dairy system

\section{INTRODUCTION}

Cropland and pasture for the production of food, fiber, and fuel occupies nearly $40 \%$ of the earth's land surface (Foley et al., 2005), uses 3 to $8 \%$ of total energy consumption (excluding food processing and transport by agro-industries; FAO, 2000), and emits approximately $13.5 \%$ of the total anthropogenic greenhouse gases (GHG) in the world (IPCC, 2007). Moreover, agricultural activities account for $85 \%$ of global nitrous oxide $\left(\mathrm{N}_{2} \mathrm{O}\right)$ and $50 \%$ of methane $\left(\mathrm{CH}_{4}\right)$ emissions, which represent $70 \%$ of non-carbon dioxide emissions of the agricultural sector (IPCC, 2007). Most $\mathrm{N}_{2} \mathrm{O}$ emissions originate from soils due to the application of fertilizers and animal manures, and the majority of $\mathrm{CH}_{4}$ emissions come from livestock enteric fermentation, making animal agriculture an important target for emission-reduction strategies.

Land use, energy intensity, and GHG emissions can be assessed by environmental indicators derived from input-output accounting methods that center around on-farm effects, but more comprehensive estimates derive from life cycle assessment (LCA) indicators (Thomassen et al., 2008). The LCA has arisen as the preferred methodology to estimate environmental effects of agricultural-related systems (Reap et al., 2008). A recent LCA study by the Food and Agriculture Organization of the United Nations estimates that the dairy sector alone contributes $4 \%$ of total global anthropogenic GHG emissions (FAO, 2010). An analysis of 60 studies by the International Dairy Federation concludes that about $80 \%$ of the GHG emissions from dairy production originate from on-farm sources; mainly soils, crop production, cows' enteric fermentation, and 
manure (IDF, 2009). The same study estimates that on-farm processes represent $40 \%$ of the total energy consumption from dairy products manufacturing.

Numerous LCA report varying results of GHG emissions from milk production depending on milk yield per cow, dairy diets, and manure-management practices (Cederberg and Stadig, 2003; Rotz et al., 2010; Mc Geough et al., 2012; Thoma et al., 2013b). According to these studies, $\mathrm{CH}_{4}$ from gastroenteric fermentation is the largest single contributor to GHG emissions, followed by $\mathrm{CH}_{4}$ from manure management and $\mathrm{N}_{2} \mathrm{O}$ from soils where dairy feed is grown. Consequently, different studies have evaluated adjustments in dairy diet compositions to reduce enteric $\mathrm{CH}_{4}$ emissions from cows (Johnson and Johnson, 1995; Johnson et al., 2007; Martin et al., 2008). The composition of the dairy diet plays an important role in GHG emissions by (1) affecting enteric emissions from cows (a direct effect), (2) changing the quantities or types of crops grown (an indirect effect), and (3) by affecting bioenergy production (a synergistic effect).

Effectiveness of GHG mitigation methods during manure management has also been evaluated (Boadi et al., 2004; del Prado et al., 2010). The GHG emissions from dairy systems can be reduced when manure is land applied for crops or pasture fertilization, given that manure displaces synthetic fertilizers that require high fossil energy inputs. Processing dairy manure in anaerobic digesters to generate biogas can further reduce GHG emissions during storage and land application. Biogas produced during anaerobic digestion contain 50 to $65 \% \mathrm{CH}_{4}$ and can be collected and used for direct burn applications, conversion to electricity, or compressed fuel (Appels et al., 2011). The combustion of $\mathrm{CH}_{4}$, otherwise emitted from manure storage, reduces GHG emissions by converting $\mathrm{CH}_{4}$ into carbon dioxide $\left(\mathrm{CO}_{2}\right)$ and by displacing fossil fuels used to produce heat or electricity. Following digestion, the manure or digestate can still be land applied as fertilizer and emit less $\mathrm{CH}_{4}$ than nondigested manure during storage as they contains less carbon (C) and volatile solids (VS; Aguirre-Villegas et al., 2014).

The current study focuses on Wisconsin (WI), the second largest state in terms of milk production and cow population in the United States (US; USDA-NASS, 2013). As a result, the majority of the state's agricultural emissions occur in the form of enteric $\mathrm{CH}_{4}$, unlike emissions from agricultural practices in other Midwest states which occur mostly in the form of $\mathrm{N}_{2} \mathrm{O}$ from crop production (WRI, 2007). The Wisconsin Strategy for Reducing Global Warming proposes to increase the capture and use of animal $\mathrm{CH}_{4}$ for electricity or heat, reduce $\mathrm{CH}_{4}$ emissions, reduce the application of nitrogen and the overall use of chemical fertilizers, and mandate the adoption of nutrient management practices (WI Global Warming Task Force, 2008). Despite these efforts, little is known about the life cycle environmental effects and little quantitative information exists on the benefits of implementing these strategies in a dairy farm.

Dairy diets in WI typically combine corn silage, alfalfa silage, corn grain, and cotton seed with soybean meal (SBM), which is the co-product from the extraction of soy oil that is used for food or biodiesel production. More recently, dry distillers grains with solubles (DDGS), a co-product of the corn ethanol industry, has been added to dairy diets due to its low cost and availability. The corn ethanol industry in WI is currently producing nearly 1.9 billion liters of ethanol and more than 1 billion kilograms of DDGS per year, constituting the seventh larger producer in the US (Stroade et al., 2009). Dairy cows are the second main consumers of DDGS in the country after beef, which situates WI in a very competitive position to further develop the ethanol industry around the dairy sector (O'Brien, 2010). In addition, the high density of dairy cows in the state offers the potential to reduce DDGS transportation distances to reduce energy consumption, GHG emissions, and costs. Hermans et al. (2006) estimated that about $15 \%$ of the gasoline used in WI could be replaced by ethanol based on allowable DDGS consumption by the state's 1.2 million dairy cows. Similarly, biodiesel from soy oil could replace approximately $6 \%$ of the locally consumed petroleum diesel based on maximum allowable SBM consumption by the state's dairy cows. The inclusion of locally produced SBM and DDGS in the dairy diet could further reduce GHG emissions and fossil energy consumption as they do not need to be transported from out-of-state crushing facilities.

In the case of a multifunctional system where both corn ethanol and DDGS are produced, the environmental burdens should be assigned to both of these products, given that DDGS can provide benefits to the system when used as animal feed. Bremer et al. (2010) indicated that assigning GHG credits to DDGS can represent 19 to $38 \%$ of total life cycle GHG emissions of corn ethanol production. Defining how much of the inputs and environmental burdens should be attributed to the main product and how much to the co-products is one of the most controversial topics in the LCA debate, as it can have an enormous influence on the results (Aguirre-Villegas et al., 2012). The International Organization for Standardization (ISO) provides the following guidance to deal with multifunctional systems (ISO, 2006): (1) avoid allocation wherever possible by dividing unit processes into subprocesses or using system expansion to include the co-products; (2) when allocation cannot be avoided, identify physical rela- 
tionships between the multiple products and functions to partition the environmental effects; and (3) when a physical relationship cannot be established, inputs and outputs should be allocated by identifying other relationship between products and co-products (e.g., energy ratio or economic value).

Defining the system boundaries is also a methodological challenge when conducting LCA studies that integrate agriculture and bioenergy systems, given that these systems respond to different societal needs and priorities. Dairy is a well-established industry and one of the most important economic activities in WI. The main purpose of a dairy farm is the production of milk; thus, it is highly unlikely that crop production for feed would be replaced by energy crops for biofuel production. In this context, it is important to evaluate alternative ways in which the production of biofuel feedstocks can coexist or provide synergy for feed production. The objective of the current study was to estimate how different dairy diets with various concentrations of DDGS and SBM and manure-management practices with and without anaerobic digestion (AD) affect direct land use, GHG emissions, and net energy intensity of WI dairy production systems. To achieve this goal, a partial LCA of milk production was conducted by applying system expansion and boundary expansion approaches to account for the interactions that exist between the dairy and bioenergy sectors in WI. This methodology used to account for the environmental effects of integrated dairy and bioenergy systems is defined as the Green Cheese model. Ours is not the first study to integrate energy and animal agriculture systems. The Biofuel Energy Systems Simulator analyzes an integrated ethanol and beef system, which is similar from the approach adopted in the current study with the exception that the functional unit in the Biofuel Energy Systems Simulator model is ethanol the functional unit we used is milk. Milk is still the primary product in WI by volume and economic importance when compared with ethanol, which makes dairy the main driver of the Green Cheese model.

\section{MATERIALS AND METHODS}

\section{Goal and Scope}

The goal of our partial LCA was to evaluate how integrating bioenergy and dairy systems affects energy intensity, GHG emissions, and land use. The first opportunity for this integration happens at the dairy herd feed level, where corn ethanol and soybean biodiesel industries can be paired with the dairy industry to produce DDGS and SBM according to animal feed requirements. This approach expands the boundaries of current dairy systems in WI into more comprehensive dairy and bioenergy multifunctional systems. The second opportunity to integrate dairy with bioenergy happens at the manure management level, where dairy manure can be used to generate biogas through $\mathrm{AD}$ for on-farm use or sale.

Two systems were analyzed: (1) a traditional dairy system that produces milk and meat, and (2) a dairy system that integrates bioenergy into its boundaries by producing milk, meat, corn ethanol, soybean biodiesel, and biogas. In the second integrated dairy and bioenergy system, the corn ethanol and soybean biodiesel industries can be seen as preprocessing operations that produce DDGS and SBM to feed dairy cows, with biofuels as co-products. Five lactating cow diets with varying amounts of DDGS and SBM and 2 manuremanagement scenarios with and without $\mathrm{AD}$ of dairy manure were modeled.

The decision tree for the model begins with the production of milk from a dairy farm under typical conditions in WI. The amount of crops grown to supply the feed ration and manure excretion are calculated based on the characteristics of the herd, components of the diet, and manure-management practices. Dietary requirements are used to calculate the inputs and outputs for crop production, prioritizing the use of dairy manure over purchased fertilizers. Produced milk is $3.5 \%$ fat and $3.0 \%$ protein, but it is corrected to $4.0 \%$ fat and $3.3 \%$ protein based on recommendations by the International Dairy Federation (IDF, 2010). The functional unit is then $1 \mathrm{~kg}$ of fat- and protein-corrected milk (FPCM) and is calculated with the equation

$$
\begin{aligned}
& \mathrm{FPCM}=\mathrm{M} \times \\
& \frac{(0.0929 \times \mathrm{MF}) \times(0.0547 \times \mathrm{MP}) \times(0.0395 \times \mathrm{ML})}{0.7436},
\end{aligned}
$$

from NRC (2001), where FPCM is in kilograms, $M=$ milk production $(\mathrm{kg}), \mathrm{MF}=$ milk fat $(\%), \mathrm{MP}=$ milk protein (\%), and ML = milk lactose (\%). The time frame of the analysis was $1 \mathrm{yr}$ and the system boundaries were defined as milk production from cradle to farm gate. The processes included in these boundaries were crop production for both dairy feed and biofuels (corn ethanol and soy biodiesel), dairy herd and diets composition, manure handling and biogas generation, corn ethanol and soybean biodiesel production, and manufacturing of nutrients, chemicals, machinery, and energy inputs (Figure 1).

\section{Life Cycle Impact Assessment}

The impact categories of depletion of abiotic resources and climate change were assessed. The indicators used 
to measure depletion of abiotic resources were direct land use (measured in meters squared) and net energy intensity (measured in MJ). Net energy intensity (NEI) is defined as the net energy from activities related to milk and bioenergy production and is calculated as the difference between the energy inputs (required energy) and energy outputs (supplied energy). The avoided energy from bioenergy production is discounted when system expansion is applied to partition the burdens between products and co-products:

$$
\mathrm{NEI}=\frac{\mathrm{E}_{\mathrm{I}}-\mathrm{E}_{\mathrm{O}}}{\mathrm{FPCM}}
$$

where NEI is in megajoules per kilogram of FPCM, $E_{\mathrm{I}}$ $=$ energy inputs to the system, including on-farm and off-farm inputs for crops and biofuels production (MJ), $\mathrm{E}_{\mathrm{O}}=$ energy generated in form of biofuel or biogas $(\mathrm{MJ})$, and FPCM is in kilograms. Avoided energy is determined based on how much fossil fuels (gasoline, petro-diesel, and natural gas) are displaced by renewable fuels (ethanol, biodiesel, and biogas) based on its energy content. Negative NEI indicates that the system produces more energy than it consumes, whereas positive NEI indicates an energy-losing system.

Climate change is measured through GHG emissions, which are characterized in kilograms of $\mathrm{CO}_{2}$ equivalents $\left(\mathbf{C O}_{2}\right.$-eq) over $100 \mathrm{yr}$ according to the CML (2001) method. It is assumed that biotic $\mathrm{CO}_{2}$ (emitted from biomass sources) is recaptured by plants within the time frame of the LCA; therefore, biotic $\mathrm{CO}_{2}$ emissions are not included in the analysis. The characterization factor for biotic $\mathrm{CH}_{4}$ is adjusted to 22.25 (Muñoz et al., 2012). Given that the molecular masses of $\mathrm{CO}_{2}$ and $\mathrm{CH}_{4}$ are different, the $\mathrm{CH}_{4}$ emission factor has to be reduced by 2.75 to account for the $\mathrm{C}$ uptake as $\mathrm{CO}_{2}$ through plant photosynthesis, as explained in the modeling principles of the LCA software Gabi and Simapro and the Recipe harmonization method (Goedkoop et al., 2013; PRe-sustainability, 2013; Schuller et al., 2013).

\section{Life Cycle Inventory}

Life cycle inventory data are obtained from the literature, mathematical equations, and the US Life Cycle Inventory (NREL, 2010) and Ecoinvent 2.0 US (Ecoinvent Centre, 2007) databases accessed through GaBi 4 Professional software (PE International, 2010). Database inventory include nitrogen $(\mathrm{N})$, phosphorus $(\mathrm{P})$, and potassium $(\mathrm{K})$ fertilizers, diesel, gasoline, natural gas, liquefied petroleum gas, and cotton production. The electricity matrix represents the mix of fuels that are part of the electric grid of WI and is presented in Table A1 in the Appendix.
Herd Structure and Nutrition. The modeled dairy farm is located in WI and produces $10,000 \mathrm{~kg}$ of milk per day at $3.0 \%$ protein, $3.5 \%$ fat, and $4.85 \%$ lactose concentrations, which are representative of WI (AgSource, 2009). To achieve this milk production, the farm houses 286 lactating cows $(650 \mathrm{~kg}$ of BW), 173 growing heifers (347 kg of BW), 41 mature heifers and dry cows (285 $\mathrm{kg}$ of BW), and 9 calves up to 1 mo old (52 kg of BW) in freestall barns (Powell et al., 2008). It is assumed that the dry period is $62 \mathrm{~d}$, the calving interval is $14 \mathrm{mo}$, and the annual adult replacement rate including mortality and culling is $35.8 \%$, which are typical values for WI dairies (AgSource, 2009). The annual mortality rate is $1.8 \%$ for weaned heifers and $7.8 \%$ for unweaned heifers (USDA, 2007), and the newborn female-to-male ratio is 0.47 (Del Rio et al., 2007). It is assumed that animals achieve their mature weight at $21 \mathrm{mo}$ old and that all heifers needed to maintain the herd size are raised on-farm as replacements. For nutrition purposes, nonlactating animals are divided into 3 categories: heifers from 1 to 11 mo old; heifers from 12 to $21 \mathrm{mo}$ old; and heifers older than $21 \mathrm{mo}$ old and dry cows. Nitrogen, P, and K flows from feed to milk and manure are calculated based on DMI and nutrient intake values according to (NRC, 2001; Table A2). Energy requirements for housing and milking are $0.062 \mathrm{MJ} / \mathrm{kg}$ of milk and include space heating, ventilation, lighting, milking, milk cooling, and water heating (ECW, 2009).

Diet Scenarios. The reference diet is representative of management practices in WI (L. Armentano, University of Wisconsin-Madison, personal communication) and is formulated separately for young stock, nonlactating cows, and lactating cows (Table 1). This is done to meet maintenance, growth, pregnancy, and milk production requirements (NRC, 2001). Alterations of the reference diet are formulated to represent different forage types as well as feeding of concentrates derived from biofuels production. It is assumed that calves younger than 1 mo do not receive solid feed and are fed milk only at a $4 \mathrm{~kg}$ of milk/d rate. Heifers are fed harvested alfalfa and corn silage, with the difference being that the diet of heifers between 1 and 11 mo is supplemented with concentrate. Six diet scenarios were formulated for lactating cows based on RUP and RDP requirements. These scenarios included a reference diet scenario representative of the system that does not integrate dairy and bioenergy production, and 5 diet scenarios that represent the integrated dairy and bioenergy system: one diet with equal amounts of corn silage and alfalfa silage, and equal amounts of DDGS and SBM (CADS); 2 diets with more corn silage than alfalfa silage, one maximizing DDGS (CSDG) and one maximizing SBM (CSSB); and 2 diets with more 

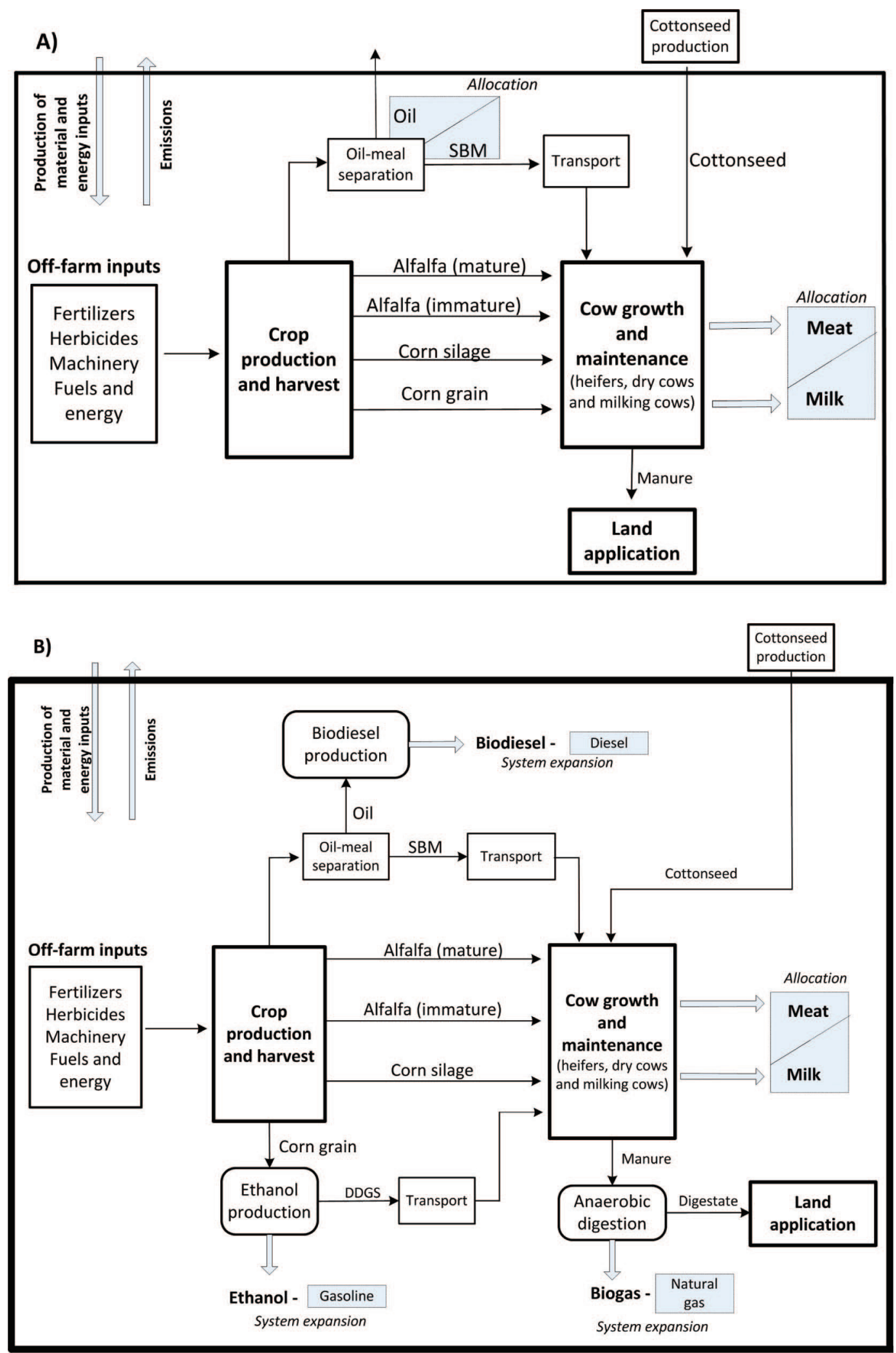

Figure 1. Cradle-to-farm gate boundaries of (A) the reference system and (B) the integrated dairy and bioenergy system. Allocation and system expansion decisions are shown with gray shaded boxes and italics. SBM = soybean meal. Color version available online. 
Table 1. Diet composition for nonlactating cows grouped into heifers younger than 10 mo, heifers between 11 and 21 mo, and heifers older than 21 mo and dry cows; and for lactating cows according to the reference system and the 5 diets that integrate dairy and bioenergy production by including varying amounts of soybean meal (SBM) and dry distillers grains with solubles (DDGS)

\begin{tabular}{|c|c|c|c|c|c|c|c|c|c|}
\hline \multirow[b]{2}{*}{ Feed ingredient } & \multicolumn{3}{|c|}{$\begin{array}{c}\text { Nonlactating cows } \\
\text { (kg of DMI/animal per day) }\end{array}$} & \multicolumn{6}{|c|}{$\begin{array}{c}\text { Lactating cows } \\
\text { (kg of DMI/lactating cow per day) }\end{array}$} \\
\hline & $\begin{array}{l}\text { Heifers } \\
(1-10 \mathrm{mo})\end{array}$ & $\begin{array}{c}\text { Heifers } \\
(11-21 \mathrm{mo})\end{array}$ & $\begin{array}{c}\text { Heifers } \\
(>21 \text { mo }) \text { and } \\
\text { dry cows }\end{array}$ & Reference $^{1}$ & $\mathrm{CADS}^{2}$ & $\mathrm{CSDG}^{3}$ & $\mathrm{CSSB}^{4}$ & $\mathrm{ASDG}^{5}$ & $\mathrm{ASSB}^{6}$ \\
\hline Alfalfa silage (mature) & 2.01 & 6.55 & 3.99 & - & - & - & - & - & - \\
\hline Alfalfa silage ${ }^{7}$ (immature) & - & - & - & 8.0 & 6.5 & 5.0 & 5.0 & 8.0 & 8.0 \\
\hline Corn grain (ground, dry) & 0.46 & - & - & 6.6 & 6.1 & 3.0 & 5.6 & 6.1 & 6.6 \\
\hline $\mathrm{SBM}^{9}$ & 0.28 & - & - & 0.8 & 0.6 & - & 1.5 & - & 0.8 \\
\hline $\mathrm{DDGS}^{10}$ & 0.53 & - & - & - & 0.6 & 4.1 & - & 1.3 & - \\
\hline Total & 5.05 & 11.91 & 7.25 & 22.3 & 22.2 & 22.1 & 22.1 & 22.4 & 22.3 \\
\hline
\end{tabular}

\footnotetext{
${ }^{1}$ The reference system includes SBM as a protein supplement, but it does not include the burdens and benefits of the biodiesel refining process into the system.

${ }^{2} \mathrm{CADS}=$ equal amounts of corn silage and alfalfa silage, and equal amounts of DDGS and SBM.

${ }^{3} \mathrm{CSDG}=$ more corn silage than alfalfa silage and maximizes DDGS content.

${ }^{4} \mathrm{CSSB}=$ more corn silage than alfalfa silage and maximizes SBM content.

${ }^{5} \mathrm{ASDG}=$ more alfalfa silage than corn silage and maximizes DDGS content.

${ }^{6} \mathrm{ASSB}=$ more alfalfa silage than corn silage and maximizes SBM content and is equivalent to the reference system, with the difference that it integrates the biodiesel refining process into the system.

${ }^{7}$ Assuming $23.2 \% \mathrm{CP}$ and $36.7 \% \mathrm{NDF}$ for alfalfa silage on a DM basis.

${ }^{8}$ Assuming $8.8 \% \mathrm{CP}$ and $45 \% \mathrm{NDF}$ for corn silage on a DM basis.

${ }^{9}$ Assuming $53.8 \% \mathrm{CP}$ and $9.8 \% \mathrm{NDF}$ for SBM on a DM basis.

${ }^{10}$ Assuming $29.7 \% \mathrm{CP}$ and $38.8 \% \mathrm{NDF}$ for DDGS on a DM basis.
}

alfalfa silage than corn silage, one maximizing DDGS (ASDG) and one diet maximizing SBM (ASSB). All lactating cow diets target a CP concentration of $17 \%$ based on NRC (2001) recommendations.

Crop Production. Chemicals, energy, fuels, machinery, and nutrients required to produce crops for dairy feed, corn ethanol, and soybean biodiesel are listed in Table 2 and the related primary energy required for their manufacturing is presented in Table A3. Fossil fuel (gasoline, diesel, liquefied petroleum gas, natural gas) and renewable fuel (biogas, ethanol, and biodiesel) consumption are calculated based on energy density values (Table A4). Nitrogen, P, and K are applied according to crop requirements, prioritizing the use of dairy manure over purchased fertilizers, which are only included into the system when nutrient targets are not met with manure. It is assumed that all of the $\mathrm{P}$ and $\mathrm{K}$ from manure applied to soils are available to plants, but just $50 \%$ of the applied N (Beegle et al., 2008). The land area required to produce dairy feed crops is calculated from yield averages for alfalfa silage (7,865 kg of DM/ha), corn silage (13,097 kg of DM/ha), corn grain $(7,591 \mathrm{~kg}$ of DM/ha), soybean $(2,386 \mathrm{~kg}$ of $\mathrm{DM} / \mathrm{ha})$, and cotton seed (1,031 kg of DM/ha; USDANASS, 2009, 2010). The total area required to produce corn grain and soybeans is considered in integrated bioenergy and dairy scenarios given that the boundar- ies of the system are expanded to include ethanol and biodiesel production.

Agricultural lime $\left(\mathrm{CaCO}_{3}\right)$ requirements for crops are calculated as the sum of lime required to supply calcium removal in harvested material, neutralize the potential acidification rate of the crop $\left(50 \mathrm{~g}\right.$ of $\mathrm{CaCO}_{3} /$ kmol of $\mathrm{H}^{+}$; Avila et al., 2005), and neutralize the potential acidity from nitrification and mineralization of $\mathrm{N}$ fertilizers $\left(2.45 \mathrm{~kg}\right.$ of $\mathrm{CaCO}_{3} / \mathrm{kg}$ of $\mathrm{N}$ fertilizer; Sinistore, 2008; Table A5), minus lime displaced due to the potential alkalinity of the manure $\left(1.12 \mathrm{~kg}\right.$ of $\mathrm{CaCO}_{3} /$ $\mathrm{kg}$ of N manure; Sinistore, 2008).

Manure Management and Biogas Generation. Manure excretion and TS were calculated for each cow type (Table 3 ). It was assumed that VS constitute $85 \%$ of excreted TS for all cow types (ASABE, 2005). Two manure management scenarios were considered in the analysis: direct land-applied manure (no processing) and manure $\mathrm{AD}$. In the first management scenario, manure was collected daily from the freestall barns with an alley scraper that consumes $0.45 \mathrm{kWh} / \mathrm{ton}$ of collected manure (calculated from survey data from 19 WI dairy farms; S. Sanford, University of WisconsinMadison, personal communication). It was assumed that chopped straw at $10 \%$ moisture was used as the bedding material, which was also collected from the barns. The area exposed to manure in the barns was 3.5 
Table 2. Material, chemical, energy, and nutrient inputs for crops production

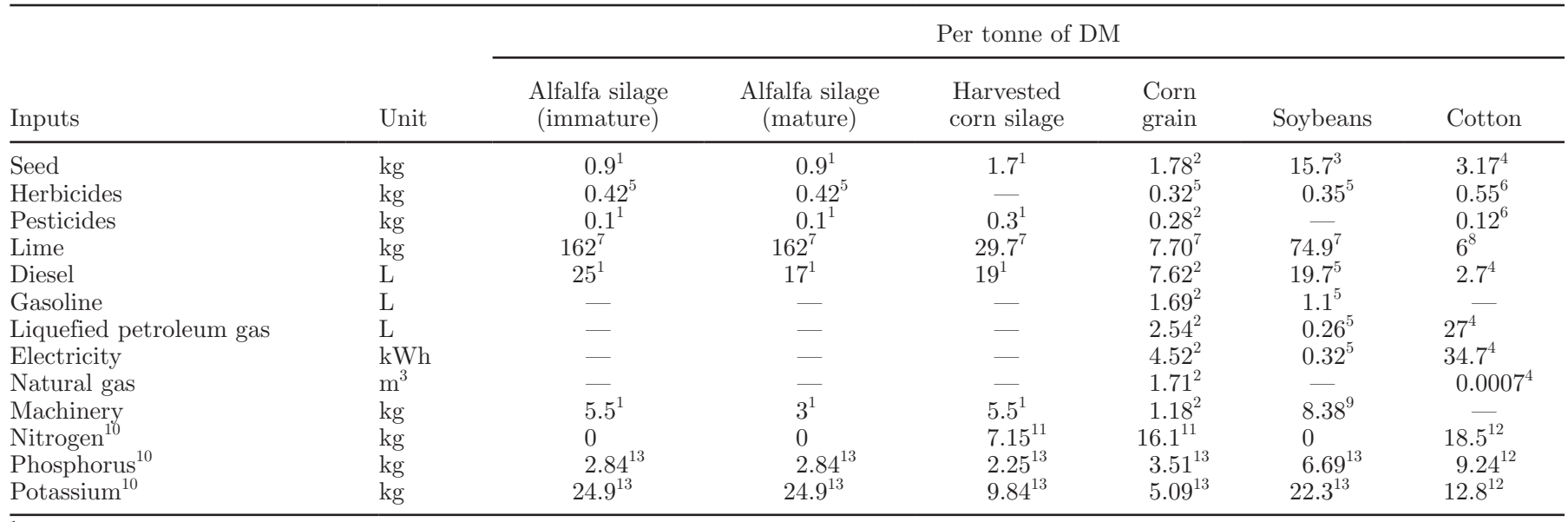

${ }^{1}$ Average for the United States (Rotz et al., 2010).

${ }^{2}$ Average for Wisconsin (WI; Kraatz et al., 2009).

${ }^{3}$ Average for WI (Pradhan et al., 2011).

${ }^{4}$ Average for the United States (USDA-ERS, 2001).

${ }^{5}$ Average for WI (Kim and Dale, 2004).

${ }^{6}$ Average for Texas (USDA-NASS, 2008).

${ }^{7}$ Calculated based on lime requirements to supply calcium removal in harvested material and neutralize acidification rate, and on amounts of manure and nitrogen fertilizer applied.

${ }^{8}$ Average for the United States (NREL, 2010).

${ }^{9}$ Average for the United States (Pimentel and Patzek, 2005).

${ }^{10}$ Total requirements of nitrogen, phosphorus, and potassium, which are supplied by both manure and purchased fertilizers.

${ }^{11}$ Data sourced from USDA-NRCS (2009).

${ }^{12}$ Data sourced from TAES (2000, 2001, 2006).

${ }^{13}$ Data sourced from Laboski and Peters (2012).

$\mathrm{m}^{2}$ per animal older than $21 \mathrm{mo}$ and $2.35 \mathrm{~m}^{2}$ per animal younger than 21 mo (Rotz and Oenema, 2006). After collection, manure was transported to a $4.5-\mathrm{m}$ deep lined, uncovered pond, a process that consumes 0.22 $\mathrm{kWh} /$ ton of transported manure. It was assumed that manure was stored for periods of 6 mo at $8 \%$ TS content, which promotes the formation of a natural crust on the surface (Rotz et al., 2011). Agitation was done before emptying the manure storage with an electrical pump at $0.22 \mathrm{kWh} / \mathrm{ton}$ of manure. Manure was then land applied by surface broadcast 2 times a year (in spring and fall) in a $179-\mathrm{kW}$ (240 HP) and $35,900-\mathrm{m}^{3}$ (9,500 gallon) truck in cycles of $0.2 \mathrm{~h}$ (including travel and application) at rates of $0.43 \mathrm{l}$ diesel/ton of applied manure. This rate was calculated based on field studies conducted in the Great Lakes Region (Hadrich et al., 2010) and the (ASABE, 2006) diesel consumption equation.

The second manure management scenario considered the addition of a digester, where the collected manure (at $85 \%$ VS of TS) and chopped straw (at 95.9\% VS of TS) were processed into biogas and digestate (Møller et al., 2004). Biogas was available to the farm for further production of electricity, heat, or compressed gas, and digestate was stored and land applied by surface broadcast in spring and fall. Biogas was produced at yields of $0.268 \mathrm{~m}^{3} / \mathrm{kg}$ of VS (Berglund and Börjesson, 2006) with $65 \% \mathrm{CH}_{4}$ and $35 \% \mathrm{CO}_{2}$ composition (Appels et

Table 3. Manure excretion and bedding material to be handled

\begin{tabular}{lccc}
\hline Animal category & $\begin{array}{c}\text { Gross manure } \\
\text { production } \\
\text { (kg/animal per day) }\end{array}$ & $\begin{array}{c}\text { Manure TS } \\
\text { (\% of excreted manure) }\end{array}$ & $\begin{array}{c}\text { Bedding }{ }^{1} \\
(\mathrm{~kg} / \mathrm{animal} \text { per day) }\end{array}$ \\
\hline Lactating cow & 67.8 (Equation A10) & 12.8 (Equation A14) & 1.75 \\
Heifers up to 21 mo old & 27.0 (Equation A11) & 17.0 (ASABE, 2005) & 0.90 \\
Heifers older than 21 mo old and dry cows & 30.4 (Equation A12) & 15.3 (Equation A15) & 1.75 \\
Calves & 4.2 (Equation A13) & 4.0 (ASABE, 2005) & 0.15 \\
\hline
\end{tabular}

${ }^{1}$ Assuming $2.7 \mathrm{~kg}$ of chopped straw per 1,000 kg of animal weight (Midwest Plan Service, 2000). 
al., 2011). The energy inputs for the digester operation were calculated based on a $28 \%$ energy input-output ratio in relation to the energy content of the produced biogas (Berglund and Börjesson, 2006).

Biofuels Production. Inputs and outputs related to the biorefining process of corn ethanol and soybean biodiesel were included in the analysis of diet scenarios that integrate dairy and bioenergy. Biofuels production volumes were scaled to the amounts of DDGS and SBM used to feed the dairy herd. It was assumed that the production of soybean biodiesel yields $0.18 \mathrm{~kg}$ of biodiesel/kg of soybeans (Pimentel and Patzek, 2005) and $0.79 \mathrm{~kg}$ of SBM $/ \mathrm{kg}$ of soybeans (Wang et al., 2011), and the production of corn ethanol yields $0.34 \mathrm{~kg}$ of etha$\mathrm{nol} / \mathrm{kg}$ of corn (Patzek, 2004) and $0.26 \mathrm{~kg}$ of DDGS $/ \mathrm{kg}$ of corn (Wang et al., 2011). It was assumed that DDGS and SBM were transported in 20-ton diesel trucks an average distance of $125 \mathrm{~km}$ based on the national DDGS transportation distance average in the US (Babcock et al., 2008). This requires a diesel consumption of $1.8 \mathrm{~kg} /$ ton of transported DDGS or SBM.

GHG Emissions. Greenhouse gases are emitted from biomass (biotic) and fossil sources. Biotic emissions are a result of plant decomposition, animal digestion, respiration, and microbial activity in manure (it was assumed that no changes occurred in the carbon content of soils). Fossil emissions come from the combustion of fossil energy sources. The GHG emissions from enteric fermentation, crop production, manure handling, and biogas generation, and biofuels production are presented in Table 4. Enteric $\mathrm{CH}_{4}$ emissions are estimated with the method developed by Moe and Tyrrell (1979), which accounts for the chemical composition change (nonstructural carbohydrate, hemicellulose, and cellulose fractions) in each of the analyzed diet scenarios. The GHG from crops production and manure handling are calculated through emission factors and equations from the literature. For the manure-management scenario with $\mathrm{AD}$, it is assumed that all $\mathrm{CH}_{4}$ from biogas is converted to $\mathrm{CO}_{2}$ through combustion. The production of biogas reduces the total amount of VS in manure, decreasing $\mathrm{CH}_{4}$ emissions from manure storage after digestion.

\section{Allocating Environmental Effects Among Co-Products}

Both systems (with and without integration of bioenergy production) are multifunctional, and, thus, require a method to allocate the environmental burdens among milk and co-products. In the reference system, there is a multifunctionality problem between SBM and oil at the input level and meat and milk at the output level. In the integrated dairy and biofuels systems, additional multifunctionality exists at the output level between milk, meat, ethanol, biodiesel, and biogas. The ISO recommends avoiding allocation by subdivision or system expansion. Subdivision can be done when the inputs and outputs of a process can be assigned entirely to a specific product (ISO, 2006). This is not the case for the evaluated system, as the processes are shared among multiple products. The next approach recommended by ISO is to apply system expansion, which can be done when an alternative way of delivering the same function of the evaluated co-products is available, but provided by different systems (Azapagic and Clift, 1999). This approach can be applied for the energy coproducts ethanol, biodiesel, and biogas, as they provide the same function as gasoline, diesel, and natural gas. The method referred to as avoided burdens is applied for corn ethanol, soybean biodiesel, and biogas under the assumption that the production of these fuels displaces an equal amount of gasoline, petro-diesel, and natural gas on an energy-content basis (Azapagic and Clift, 1999; Curran, 2006; Finnveden et al., 2009; Suh et al., 2010). With this approach, the environmental burdens allocated to milk are calculated to include the credits for the avoided environmental burdens of producing gasoline, diesel, and natural gas by subtracting them from the total burdens of the system (Azapagic and Clift, 1999). As stated by Curran (2006) and Azapagic and Clift (1999), this process can result in negative accounting if the burdens of the systems being replaced are larger than the burdens of the system under study. Negative indicators have been reported by several LCA studies, especially when the avoided burdens method is applied to include fossil energy products (Kim and Dale, 2005; Thomassen et al., 2008; Jury et al., 2010; Michel et al., 2010; Lim et al., 2011; Poeschl et al., 2012).

The multifunctionality problem of the reference system is dealt by applying allocation, as multiple comparable substitutes exist for meat (at the output level) and oil (at the input level), which complicates conducting system expansion. A physical ratio based on mass is applied at the input level to allocate the environmental burdens between SBM and oil. A ratio of $0.786 \mathrm{~kg}$ of $\mathrm{SBM} / \mathrm{kg}$ of soybean is calculated based on Wang et al. (2011), who reported yields of $21.4 \mathrm{~kg}$ of SMB per bushel of soybean. Finally, an allocation ratio is developed based on the nutritional content of milk and meat. Developing an allocation ratio based on the nutritional content of food products has been done already by other authors (Aguirre-Villegas et al., 2012; O'Brien et al., 2014). In this system, meat is valued based on its fat and protein content compared with the fat and protein content of milk produced during the same time period: 
Table 4. Sources, factors, and equations used to calculate greenhouse gas (GHG) emissions

\begin{tabular}{|c|c|c|}
\hline Emission and source & Emission factor/equation & Reference \\
\hline \multicolumn{3}{|l|}{$\mathrm{CH}_{4}$} \\
\hline Enteric fermentation & Equation A16 & (Moe and Tyrrell, 1979) \\
\hline Manure application $^{1}$ & Equation A17 & (Chianese et al., 2009) \\
\hline Manure storage & Equation A19 & (Chianese et al., 2009) \\
\hline \multicolumn{3}{|l|}{$\mathrm{N}_{2} \mathrm{O}$ direct } \\
\hline Manure and fertilizer application & $0.01 \mathrm{~kg}$ of $\mathrm{N}_{2} \mathrm{O}-\mathrm{N} / \mathrm{kg}$ of $\mathrm{N}$ & (IPCC, 2006a) \\
\hline \multicolumn{3}{|l|}{$\mathrm{N}_{2} \mathrm{O}$ indirect } \\
\hline Ämmonia volatilization & $0.01 \mathrm{~kg}$ of $\mathrm{N}_{2} \mathrm{O}-\mathrm{N} / \mathrm{kg}$ of $\mathrm{NH}_{3}-\mathrm{N}$ & (IPCC, 2006b) \\
\hline Leaching $^{2}$ & $0.0075 \mathrm{~N}_{2} \mathrm{O}-\mathrm{N} / \mathrm{kg}$ of $\mathrm{N}$ & (IPCC, 2006b) \\
\hline From $\mathrm{NO}_{\mathrm{x}}$ & $0.01 \mathrm{~kg}$ of $\mathrm{N}_{2} \mathrm{O}-\mathrm{N} / \mathrm{kg}$ of $\mathrm{NO}_{\mathrm{x}}-\mathrm{N}$ & (IPCC, 2006b) \\
\hline \multicolumn{3}{|c|}{ 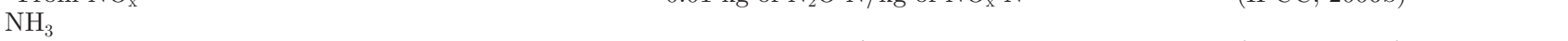 } \\
\hline Fertilizer application & $0.1 \mathrm{~kg}$ of $\mathrm{NH}_{3}-\mathrm{N} / \mathrm{kg}$ of $\mathrm{N}$ & (IPCC, 2006a) \\
\hline Manure application & Equation A20 & (Jokela et al., 2004) \\
\hline \multicolumn{3}{|c|}{ 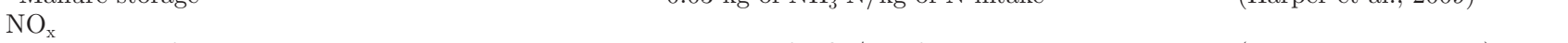 } \\
\hline \multicolumn{3}{|l|}{$\mathrm{CO}_{2}$-equivalents $\left(\mathrm{CO}_{2}\right.$-eq) } \\
\hline Lime application & $1.4 \mathrm{~kg}$ of $\mathrm{CO}_{2}$-eq $/ \mathrm{kg}$ of $\mathrm{CaCO}_{3}$ & (PE International, 2010) \\
\hline Methane combustion & $0.002 \mathrm{~kg}$ of $\mathrm{CO}_{2}-\mathrm{eq} / \mathrm{L}$ & $\mathrm{CH}_{4}+2 \mathrm{O}_{2} \rightarrow \mathrm{CO}_{2}+2 \mathrm{H}_{2} \mathrm{O}$ \\
\hline Gasoline combustion & $2.17 \mathrm{~kg}$ of $\mathrm{CO}_{2}-\mathrm{eq} / \mathrm{L}$ & $(\mathrm{NREL}, 2010)$ \\
\hline Liquefied petroleum gas (LPG) combustion & $1.76 \mathrm{~kg}$ of $\mathrm{CO}_{2}-\mathrm{eq} / \mathrm{L}$ & (NREL, 2010) \\
\hline Natural gas combustion & $0.002 \mathrm{~kg}$ of $\mathrm{CO}_{2}$-eq/L & (NREL, 2010) \\
\hline Corn ethanol combustion & $1.94 \mathrm{~kg}$ of $\mathrm{CO}_{2}-\mathrm{eq} / \mathrm{L}$ & (Pimentel and Patzek, 2005) \\
\hline Soy biodiesel combustion & $2.48 \mathrm{~kg}$ of $\mathrm{CO}_{2}-\mathrm{eq} / \mathrm{L}$ & (Pimentel and Patzek, 2005) \\
\hline Petro-diesel combustion & $2.73 \mathrm{~kg}$ of $\mathrm{CO}_{2}-\mathrm{eq} / \mathrm{L}$ & (NREL, 2010) \\
\hline $\mathrm{N}$ fertilizer production & $1,968 \mathrm{~g}$ of $\mathrm{CO}_{2}-\mathrm{eq} / \mathrm{kg}$ & (NREL, 2010) \\
\hline $\mathrm{P}$ fertilizer production & $394 \mathrm{~g}$ of $\mathrm{CO}_{2}-\mathrm{eq} / \mathrm{kg}$ & (NREL, 2010) \\
\hline K fertilizer production & $533 \mathrm{~g}$ of $\mathrm{CO}_{2}-\mathrm{eq} / \mathrm{kg}$ & (Kim and Dale, 2004) \\
\hline Herbicides production & $17,242 \mathrm{~g}$ of $\mathrm{CO}_{2}$-eq $/ \mathrm{kg}$ & (West and Marland, 2002) \\
\hline Pesticides production & $18,534 \mathrm{~g}$ of $\mathrm{CO}_{2}-\mathrm{eq} / \mathrm{kg}$ & (Kim and Dale, 2004) \\
\hline
\end{tabular}

${ }^{1}$ Assuming $8 \mathrm{~d}$ after application.

${ }^{2}$ Leaching fraction: $0.3 \mathrm{~kg}$ of N (IPCC, 2006b).

${ }^{3}$ Assuming 1.7 million $\mathrm{kg}$ of $\mathrm{CO}_{2}$-eq for grain transport and 85.6 million $\mathrm{kg}$ of $\mathrm{CO}_{2}$-eq for refining 145 million L of ethanol (drying of dry distillers grain with solubles is included).

$$
\begin{aligned}
& \text { AMM }=\text { Meat }(\mathrm{kg}) \times \text { Cows } \\
& \frac{(0.0920 \times \text { Meat Fat })+(0.0547 \times \text { Meat Protein })}{(0.0920 \times \text { FPCM fat })+(0.0547 \times \text { FPCM protein })},
\end{aligned}
$$

where $\mathrm{AMM}=$ adjusted meat mass based on its nutritional content as compared with the nutritional content of the produced milk ( $\mathrm{kg}$ of boneless meat per culled cow), Cows $=$ number of culled cows for human consumption, Meat Fat $=$ fat content in meat, Meat Protein
$=$ protein content in meat, $\mathrm{FPCM}$ fat $=$ fat content in FPCM, and FPCM protein = protein content in FPCM. This adjusted meat mass is then compared with the produced mass of milk to allocate the environmental effects between these 2 products. Boneless meat production is $195 \mathrm{~kg} /$ culled adult dairy cow (Cederberg and Stadig, 2003 , with a fat content of $6.5 \%$ and protein content of 20.7\% (Minchin et al., 2009; Franco et al., 2009). This method allocates $98.99 \%$ of the system inputs and outputs to milk and $1.01 \%$ to meat. 
Table 5. Quantities of co-products, land use, net energy intensity (NEI), and greenhouse gas (GHG) emissions for the reference system and for each of the scenarios of the integrated dairy and bioenergy system

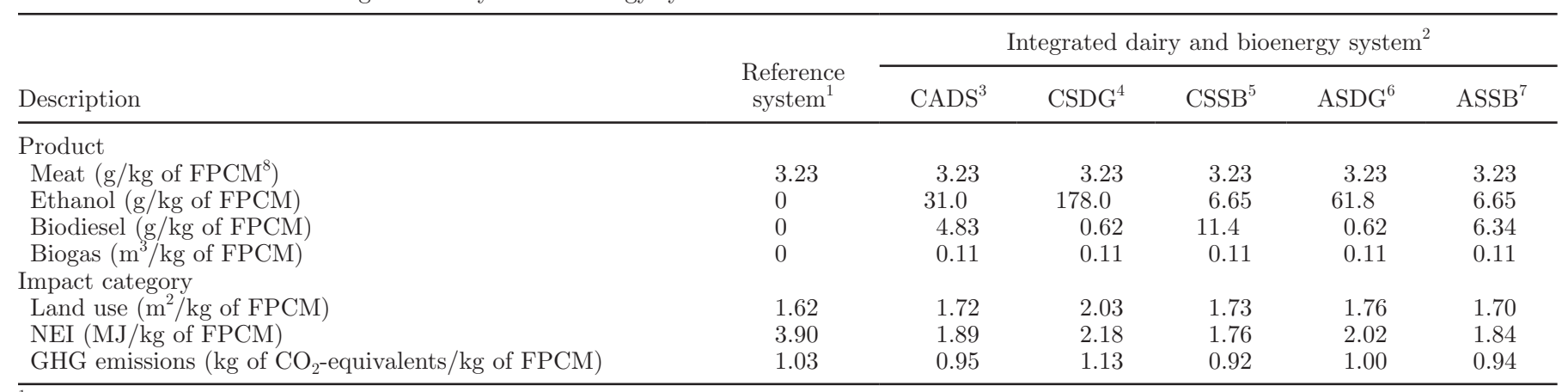

${ }^{1}$ The reference system does not include the production of bioenergy into its boundaries.

${ }^{2}$ The integrated dairy and bioenergy system includes the production of bioenergy products into its boundaries.

${ }^{3} \mathrm{CADS}=$ equal amounts of corn silage and alfalfa silage, and equal amounts of dry distillers grains with solubles (DDGS) and soybean meal (SBM).

${ }^{4} \mathrm{CSDG}=$ more corn silage than alfalfa silage and maximizes DDGS content.

${ }^{5} \mathrm{CSSB}=$ more corn silage than alfalfa silage and maximizes SBM content.

${ }^{6} \mathrm{ASDG}=$ more alfalfa silage than corn silage and maximizes DDGS content.

${ }^{7} \mathrm{ASSB}=$ more alfalfa silage than corn silage and maximizes SBM content.

${ }^{8} \mathrm{FPCM}=$ fat- and protein-corrected milk.

\section{RESULTS AND DISCUSSION}

\section{System Results Without Allocation}

Total land use, NEI, and GHG emissions for the reference system (both milk and meat) were $1.62 \mathrm{~m}^{2} / \mathrm{kg}$ of FPCM, 3.9 MJ $/ \mathrm{kg}$ of FPCM, and $1.03 \mathrm{~kg}$ of $\mathrm{CO}_{2}-\mathrm{eq} /$ $\mathrm{kg}$ of FPCM, respectively, before any allocation was applied. These results are comparable to those found in other LCA studies that report both milk and meat production previous to any allocation of environmental burdens. Capper et al. (2009) reported US averages of $1.62 \mathrm{~m}^{2} / \mathrm{kg}$ of FPCM for land use and $1.35 \mathrm{~kg}$ of $\mathrm{CO}_{2}$-eq $/ \mathrm{kg}$ of milk for GHG emissions. Cederberg and Stadig (2003) reported $3 \mathrm{MJ} / \mathrm{kg}$ of ECM for energy use and $1.05 \mathrm{~kg}$ of $\mathrm{CO}_{2}-\mathrm{eq} / \mathrm{kg}$ of ECM for GHG emissions, Mc Geough et al. (2012) reported $0.92 \mathrm{~kg}$ of $\mathrm{CO}_{2}$-eq/ $\mathrm{kg}$ of FPCM, and O'Brien et al. (2014) reported an average of $0.9 \mathrm{~kg}$ of $\mathrm{CO}_{2}-\mathrm{eq} / \mathrm{kg}$ of ECM for the US.

The integrated dairy and bioenergy system produced milk, meat, corn ethanol, soybean biodiesel, and biogas at rates that depend on the lactating cow diet scenario. Table 5 presents the production rates for these coproducts and the results for land use, NEI, and GHG emissions per kilogram of FPCM for each diet scenario before applying allocation and before conducting system expansion. Land use ranged from 1.72 to $2.03 \mathrm{~m}^{2} /$ $\mathrm{kg}$ of FPCM, NEI ranged from 1.76 to $2.18 \mathrm{MJ} / \mathrm{kg}$ of FPCM, and GHG emissions ranged from 0.92 to 1.13 $\mathrm{kg}$ of $\mathrm{CO}_{2}-\mathrm{eq} / \mathrm{kg}$ of FPCM. These results include the energy content of ethanol, biodiesel, and biogas, and the reduction in $\mathrm{CH}_{4}$ emissions from manure storage due to the production of biogas, but do not account for the credits of displacing gasoline, diesel, and natural gas. As a result, the diet that maximizes biofuels production (diet CSDG with ethanol) is the diet with the highest environmental effects for the overall multifunctional system.

\section{Results Allocated to Milk}

Land Use. The land area required for milk production in the reference system was $1.6 \mathrm{~m}^{2} / \mathrm{kg}$ of $\mathrm{FPCM}$ after allocating the environmental effects among products. Land use increased an average of $9.1 \%$ in diet scenarios that include ethanol and biodiesel production when compared with the reference system, going from 1.68 (ASSB) to 1.70 (CADS), 1.71 (CSSB), 1.74 (ASDG), and $2.01 \mathrm{~m}^{2}$ (CSDG) per $\mathrm{kg}$ of FPCM. Land use results were greater when DDGS content in the diet was maximized within scenarios with similar forage characteristics (i.e., CSDG vs. CSSB, and ASDG vs. ASSB). This was attributed to the higher DDGS content in diet CSDG when compared with the SBM content in diet CSSB (4.1 vs. $1.5 \mathrm{~kg}$ of DMI/lactating cow), and the lower yields of DDGS per kilogram of corn than SBM per kilogram of soybean $(0.33 \mathrm{~kg}$ of DDGS $/ \mathrm{kg}$ of corn vs $0.79 \mathrm{~kg}$ of SBM $/ \mathrm{kg}$ of soybean). Despite these differences, land use area was not increased in the same proportion given the higher yields of corn compared with soybean.

NEI. Net energy intensity results are detailed in Table 6 and Figure 2; NEI allocated to milk production for the reference system was $3.87 \mathrm{MJ} / \mathrm{kg}$ of FPCM. This 
result is within the 1.31 to $6.57 \mathrm{MJ} / \mathrm{kg}$ of milk range reported by the International Dairy Federation (IDF, 2009 ), and higher than the 2.55 to $2.76 \mathrm{MJ} / \mathrm{kg}$ of ECM range reported by Cederberg and Stadig (2003). The NEI was reduced, when compared with the reference system, in all diet scenarios that integrate corn ethanol and soybean biodiesel production and do not consider $\mathrm{AD}$ as a manure-management practice after system expansion. The NEI ranged from -1.74 (CSDG) to 3.17 (ASSB) MJ $/ \mathrm{kg}$ of FPCM. Lower NEI was achieved when maximizing the concentration of DDGS (CSDG) than when maximizing the concentration of SBM (CSSB). This is because DDGS can be fed at a higher concentration in the CSDG diet than SBM can in the CSSB diet, resulting in more ethanol production than biodiesel. In addition, corn ethanol has a higher biofuel yield (9 MJ/ $\mathrm{kg}$ of corn) than biodiesel (6.8 MJ/kg of soybean). The inclusion of manure AD makes all of the diet scenarios net energy producers. On average, the production of biogas contributes $1.85 \mathrm{MJ} / \mathrm{kg}$ of FPCM to the system and avoids $2.05 \mathrm{MJ} / \mathrm{kg}$ of FPCM due to the displacement of natural gas after system expansion. The overall NEI of milk production, including biofuels and biogas, ranged from -5.63 (CSDG) to -0.73 (ASSB) $\mathrm{MJ} / \mathrm{kg}$ of FPCM. The negative numbers are attributed to the system expansion approach that brings in the avoided burdens of producing diesel, ethanol, and biogas, given that the production of these fossil sources is energy intensive. Negative NEI are reported by several studies exploring energy production and applying system expansion (Kim and Dale, 2005; Thomassen et al., 2008; Jury et al., 2010; Michel et al., 2010; Lim et al., 2011; Poeschl et al., 2012).

GHG Emissions. Detailed results for GHG emissions are presented in Table 7 and Figure 3; GHG emissions allocated to milk production for the reference system were $1.02 \mathrm{~kg}$ of $\mathrm{CO}_{2}$-eq $/ \mathrm{kg}$ of FPCM. The largest single contributor to GHG emissions was enteric $\mathrm{CH}_{4}$, with $41 \%$ of total $\mathrm{GHG}$, followed by $\mathrm{CH}_{4}$ from manure storage $(27 \%), \mathrm{CO}_{2}$-eq from manufacturing the inputs for crops production $(12 \%), \mathrm{N}_{2} \mathrm{O}$ from soils (11\%), $\mathrm{CO}_{2}$-eq from milking energy use $(5 \%)$, and $\mathrm{N}_{2} \mathrm{O}$ from manure (4\%). These results are comparable to the 0.89 to $0.97 \mathrm{~kg}$ of $\mathrm{CO}_{2}$-eq $/ \mathrm{kg}$ of ECM range (depending on the allocation method) reported by Cederberg and Stadig (2003); higher than the $0.70 \mathrm{~kg}$ of $\mathrm{CO}_{2}$-eq $/ \mathrm{kg}$ of FPCM reported by Rotz et al. (2010), the 0.64 to 0.90 $\mathrm{kg}$ of $\mathrm{CO}_{2}$-eq/ $\mathrm{kg}$ of ECM range (depending on the allo-

Table 6. Process life cycle net energy intensity (NEI) results for the reference system and for each diet and manure management scenario of the integrated dairy and bioenergy system

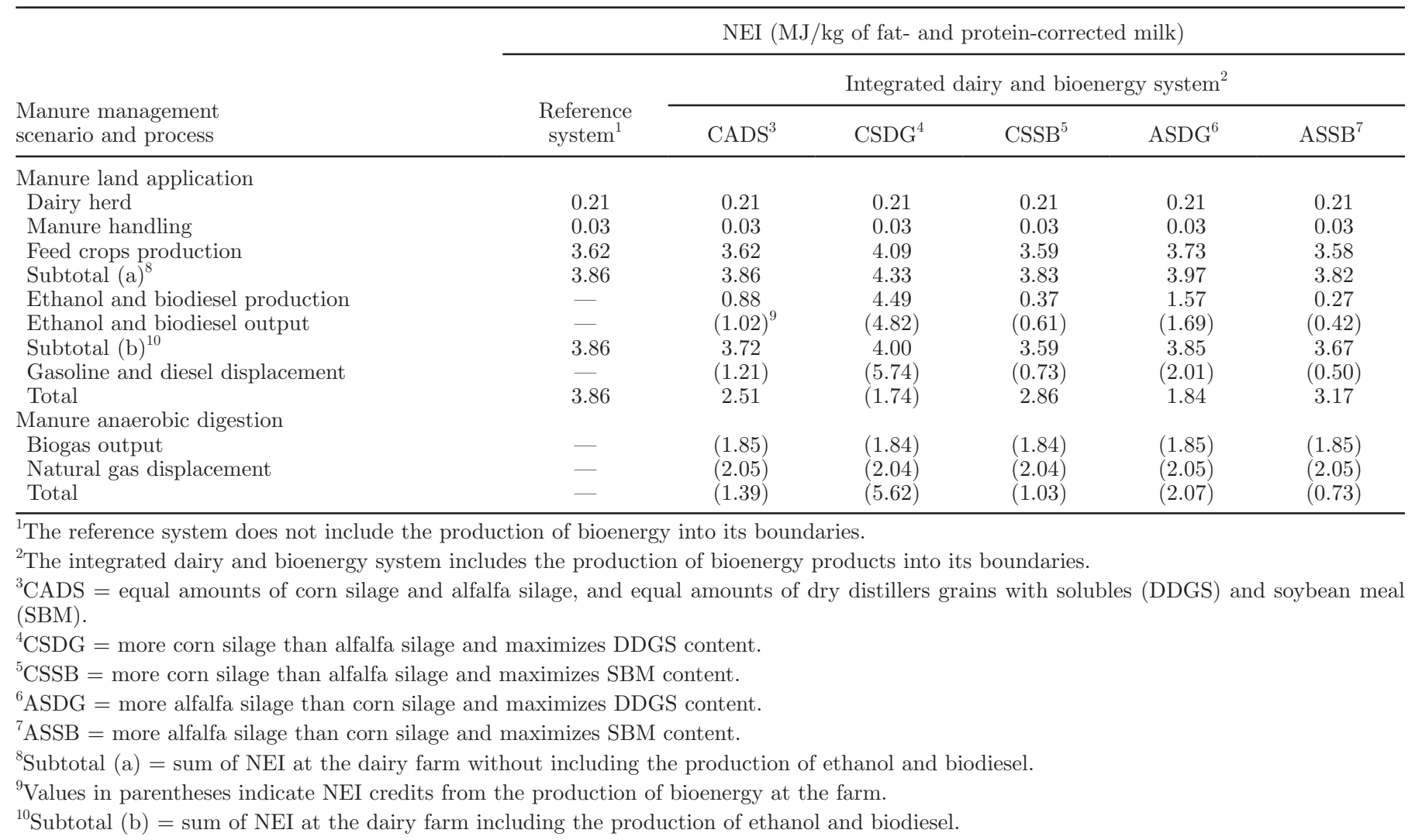


Dairy herd

Ethanol and bio-diesel production

Biogas output

Total (manure AD)
Manure handling

Ethanol and bio-diesel output

Natural gas displacement
Feed crops production

Gasoline and diesel displacement

Total (manure land-applied)

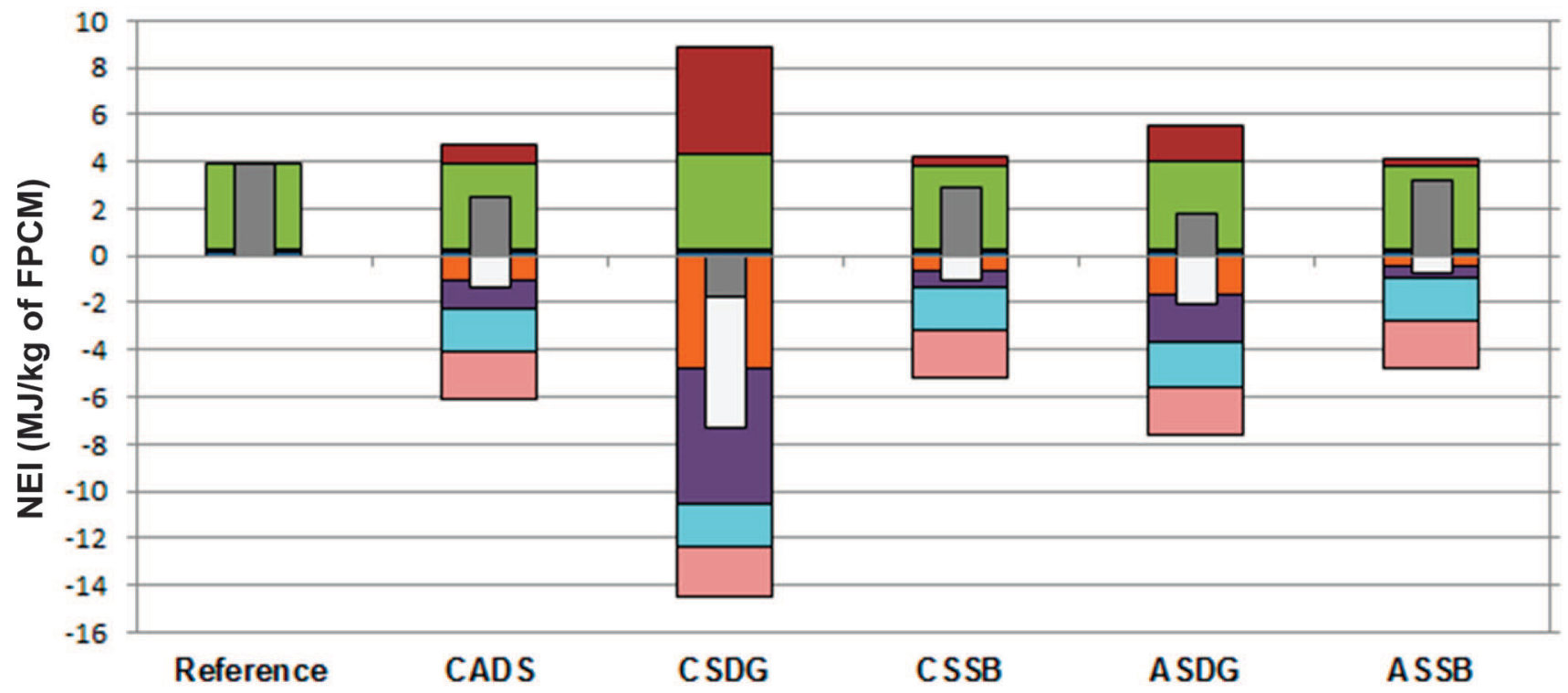

Figure 2. Process life cycle net energy intensity (NEI) results allocated to milk for the reference system and for each diet and manure management scenario of the integrated dairy and bioenergy system. The reference system does not include the production of bioenergy into its

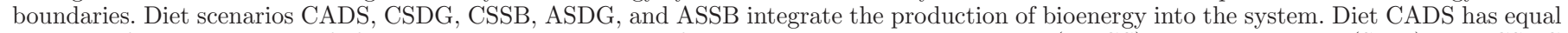

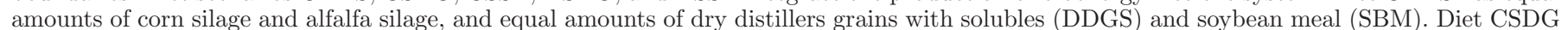

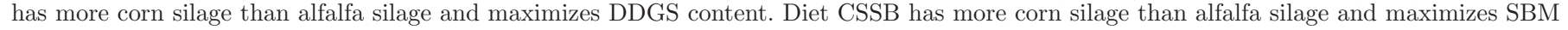

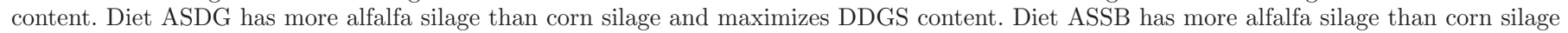
and maximizes SBM content. FPCM = fat- and protein-corrected milk; AD = anaerobic digestion.

cation method) reported by O'Brien et al. (2014), and the 0.84 to $0.92 \mathrm{~kg}$ of $\mathrm{CO}_{2}$-eq $/ \mathrm{kg}$ of FPCM reported by Mc Geough et al. (2012); and lower than the $1.35 \mathrm{~kg}$ of $\mathrm{CO}_{2}$-eq/kg of milk reported by Capper et al. (2009) and the $1.23 \mathrm{~kg}$ of $\mathrm{CO}_{2}$-eq $/ \mathrm{kg}$ of FPCM reported by Thoma et al. (2013b). Even though all of these results come from cradle-to-farm gate LCA studies, there are methodological differences that need to be considered when conducting comparisons (e.g., allocation and functional unit). Mc Geough et al. (2012) apply 2 mass-allocation approaches to assign 85.6 and $73.4 \%$ of the effects to milk. Rotz et al. (2010) apply economic allocation and assigns $91.7 \%$ of the burdens to milk, whereas Cederberg and Stadig (2003) uses economic and biological cause-effect allocation approaches to partition 92 and $85 \%$ of the environmental burdens to milk. O'Brien et al. (2014) adopted 6 different allocation strategies based on mass, protein, economic allocation, biological energy, emissions allocation, and system expansion and found a $41 \%$ difference in the proportion of GHG emissions allocated to milk. Mass allocation was the method assigning the most burdens to milk, at 98\%. Another difference is the definition of the functional unit, as Mc Geough et al. (2012) adjusted FPCM to $3.85 \%$ fat and $3.03 \%$ protein, Rotz et al. (2010) adjusted FPCM to $3.5 \%$ fat and $3.1 \%$ protein, and FAO (2010) adjusted FPCM to $4 \%$ fat and $3.3 \%$ protein as in O'Brien et al. (2014).

The average GHG emission reduction for all diet scenarios that integrate corn ethanol and soybean biodiesel production (with no AD) was 7\% when compared with the reference system. The GHG emissions allocated to milk for these diet scenarios ranged from 0.86 (CSDG) to 1.00 (ASSB) $\mathrm{kg}$ of $\mathrm{CO}_{2}$-eq/ $\mathrm{kg}$ of FPCM. The effect of biofuels production can be assessed by comparing diet scenarios within the land applied manure-management scenario. Diet CSDG (high in corn silage and DDGS) had the lowest GHG emissions and diet ASSB (high in 
Table 7. Process life cycle greenhouse gas (GHG) emissions for the reference system and for each diet and manure management scenario of the integrated dairy and bioenergy system

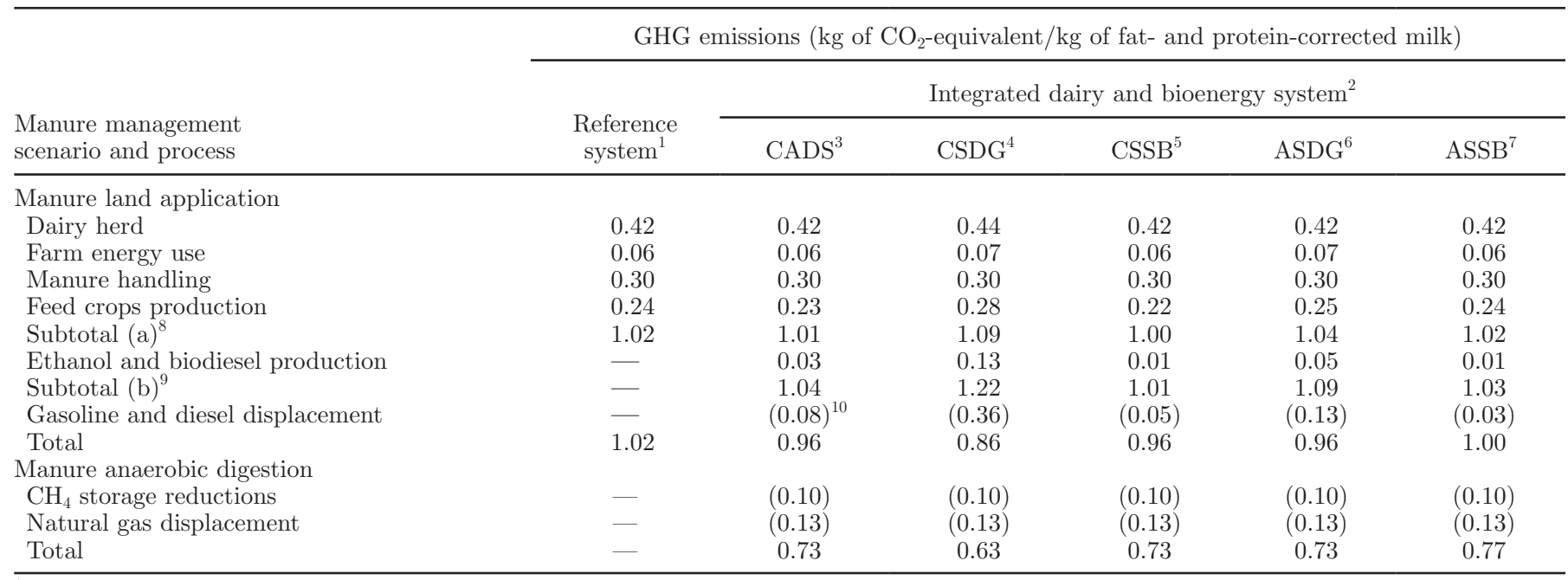

${ }^{1}$ The reference system does not include the production of bioenergy into its boundaries.

${ }^{2}$ The integrated dairy and bioenergy system includes the production of bioenergy products into its boundaries.

${ }^{3}$ CADS has equal amounts of corn silage and alfalfa silage, and equal amounts of dry distillers grains with solubles (DDGS) and soybean meal (SBM).

${ }^{4}$ CSDG has more corn silage than alfalfa silage and maximizes DDGS content.

${ }^{5} \mathrm{CSSB}$ has more corn silage than alfalfa silage and maximizes SBM content.

${ }^{6}$ ASDG has more alfalfa silage than corn silage and maximizes DDGS content.

${ }^{7}$ ASSB has more alfalfa silage than corn silage and maximizes SBM content.

${ }^{8}$ Subtotal (a) = sum of GHG emissions at the dairy farm without including the production of ethanol and biodiesel.

${ }^{9}$ Subtotal (b) = sum of GHG emissions at the dairy farm including the production of ethanol and biodiesel

${ }^{10}$ Values in parentheses indicate net energy intensity credits from the production of bioenergy at the farm.

alfalfa silage and no DDGS) has the highest emissions. This $0.14 \mathrm{~kg}$ of $\mathrm{CO}_{2}$-eq $/ \mathrm{kg}$ of $\mathrm{FPCM}$ difference was mainly attributed to the avoidance of gasoline production and combustion in diet scenarios with DDGS. However, diets CSDG and ASDG were high in DDGS but showed large differences in overall GHG emissions, which highlight the influence that the forage fraction can have on the final results. The effect of biogas generation can be assessed by comparing manure management scenarios (manure land application vs. manure $\mathrm{AD}$ ). The average effect of including $\mathrm{AD}$ on the dairy farm reduced GHG emissions from milk production by $0.23 \mathrm{~kg}$ of $\mathrm{CO}_{2}$-eq $/ \mathrm{kg}$ of $\mathrm{FPCM}$, which is lower than the $0.32 \mathrm{~kg}$ of $\mathrm{CO}_{2}-\mathrm{eq} / \mathrm{kg}$ of $\mathrm{FPCM}$ reduction reported by Rotz et al. (2010). Fifty-seven percent of this reduction is attributed to the avoided emissions from natural gas production and combustion and $43 \%$ is attributed to the decrease in $\mathrm{CH}_{4}$ emissions from manure storage. Overall, the lowest GHG emissions were obtained when DDGS were maximized in the dairy diet (CSDG) and $\mathrm{AD}$ was included as a manure management practice, given that both gasoline and natural gas are partially replaced by the ethanol and biogas produced by the system with the system expansion approach.

\section{Comparing Marginal Changes}

Changes of land use, NEI, and GHG emissions of each scenario of the integrated dairy and bioenergy system were compared with the reference system before and after allocating environmental effects to milk (Figure 4). The reference system produces milk and meat, whereas the integrated system produces ethanol, biodiesel, and biogas in addition to milk and meat. Before system expansion, diet scenarios with more DDGS used more land, emitted more GHG, and had higher NEI per kilogram of FPCM (Figure 4a). The AD contributed to reduce GHG emissions by nearly $10 \%$ and made all scenarios energy producers. After system expansion, diet scenarios with more DDGS (CSDG and ASDG) were the most effective in reducing GHG emissions and NEI when compared with other diets within the same group in terms of forage (Figure $4 \mathrm{~b}$ ). Including DDGS in the diet had a bigger influence on environmental effects than SBM given the higher ethanol yields per kilogram of DDGS DMI when compared with the yields of soybean biodiesel per kilogram of SBM DMI. The AD contributed to reduce GHG emissions by more than $20 \%$ and NEI by $100 \%$. Despite these environmental 
$\square$ Dairy herd

Feed crops production

$\square \mathrm{CH} 4$ storage reductions

Total (manure land-applied)
Farm energy use

Ethanol and bio-diesel production

Natural gas displacement
Manure handling

Gasoline and diesel displacement

Total (manure AD)

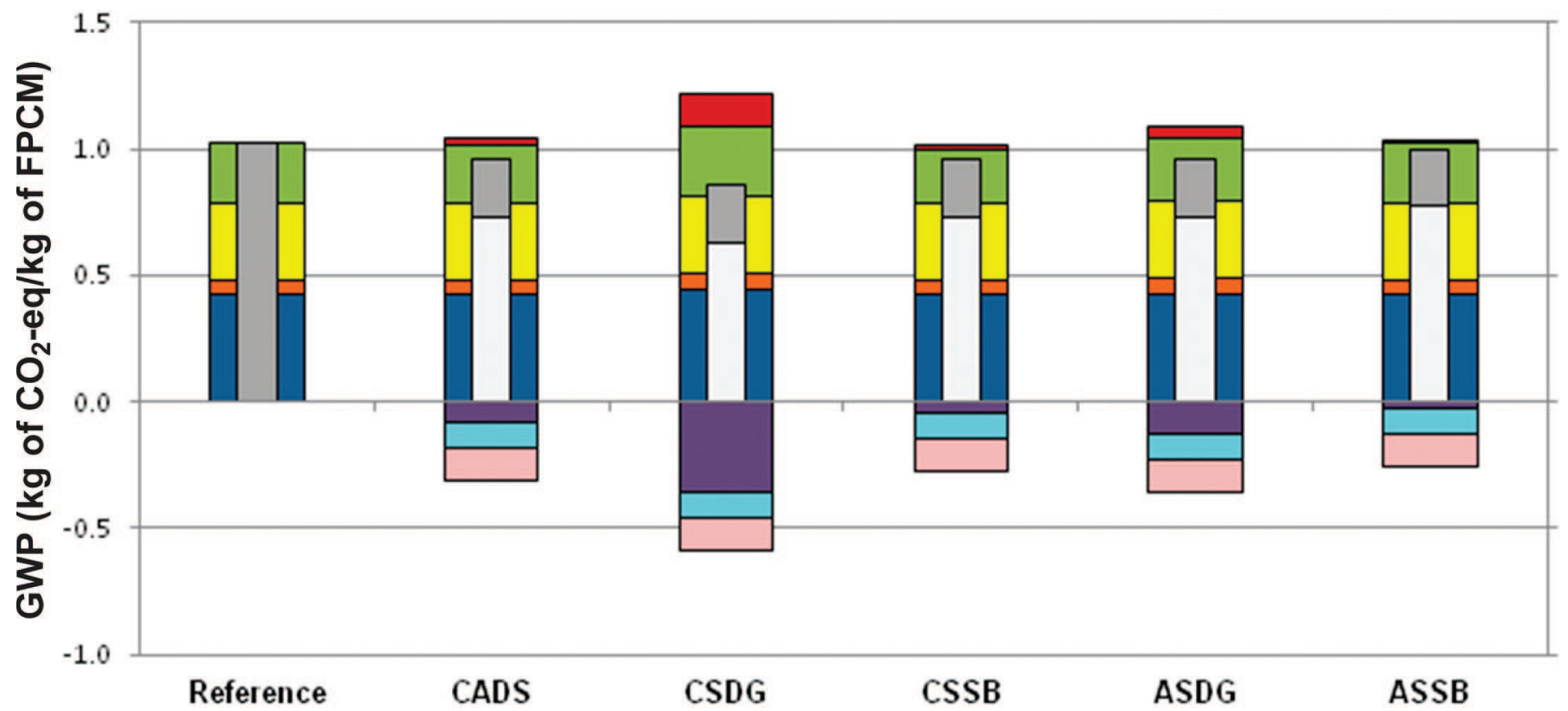

Figure 3. Process life cycle greenhouse gas (GHG) emissions allocated to milk for the reference system and for each diet and manure management scenario of the integrated dairy and bioenergy system. The reference system does not include the production of bioenergy into its boundaries. Diet scenarios CADS, CSDG, CSSB, ASDG, and ASSB integrate the production of bioenergy into the system. Diet CADS has equal amounts of corn silage and alfalfa silage, and equal amounts of dry distillers grains with solubles (DDGS) and soybean meal (SBM). Diet CSDG has more corn silage than alfalfa silage and maximizes DDGS content. Diet CSSB has more corn silage than alfalfa silage and maximizes SBM content. Diet ASDG has more alfalfa silage than corn silage and maximizes DDGS content. Diet ASSB has more alfalfa silage than corn silage and maximizes SBM content. FPCM = fat- and protein-corrected milk; $\mathrm{AD}=$ anaerobic digestion.

benefits, only $0.2 \%$ dairy farms in WI have implemented digesters. Some factors that have been limiting a wider implementation of digesters in the state are the high capital costs and the low density of manure as an energy source in comparison to other biomass feedstocks. Among some of the strategies that dairy farmers are already applying to increase the profit of their digester systems include co-digestion of manure with higher energy sources available to the farm (e.g., corn stover) and increasing the value of the digestate (i.e., digested solids used as fertilizer or soil amendment).

Our study provides a comprehensive assessment of milk production systems, but some factors might affect the estimation of environmental effects. First, even though the effects related to equipment and buildings for bioenergy production are included in the system boundaries, the effects related to milking and cropping machinery are not included in the current analysis.
The inclusion of these operations is not expected to change the results, as they have been cited to have a small influence on the total life cycle (Kim et al., 2009). Second, the model assumes no losses throughout crop harvesting and milk production; therefore, the related effects to compensate these losses are not assessed. Thoma et al. (2013a) concluded that the majority of product losses happen at the retail and consumer stages in the life cycle of milk, which are outside the boundaries of this system. In addition, yields used for crop production in this model came from average data from USDA, which reflect net quantities harvested by the farmer. As a result, the losses associated with inputs and products should be small, as should their effect on environmental impacts. Third, the effects of $\mathrm{AD}$ on $\mathrm{NH}_{3}$ or $\mathrm{N}_{2} \mathrm{O}$ volatilization after manure application to soils were not analyzed, which might underestimate $\mathrm{NH}_{3}$ and indirect $\mathrm{N}_{2} \mathrm{O}$ emissions (Aguirre-Villegas et 


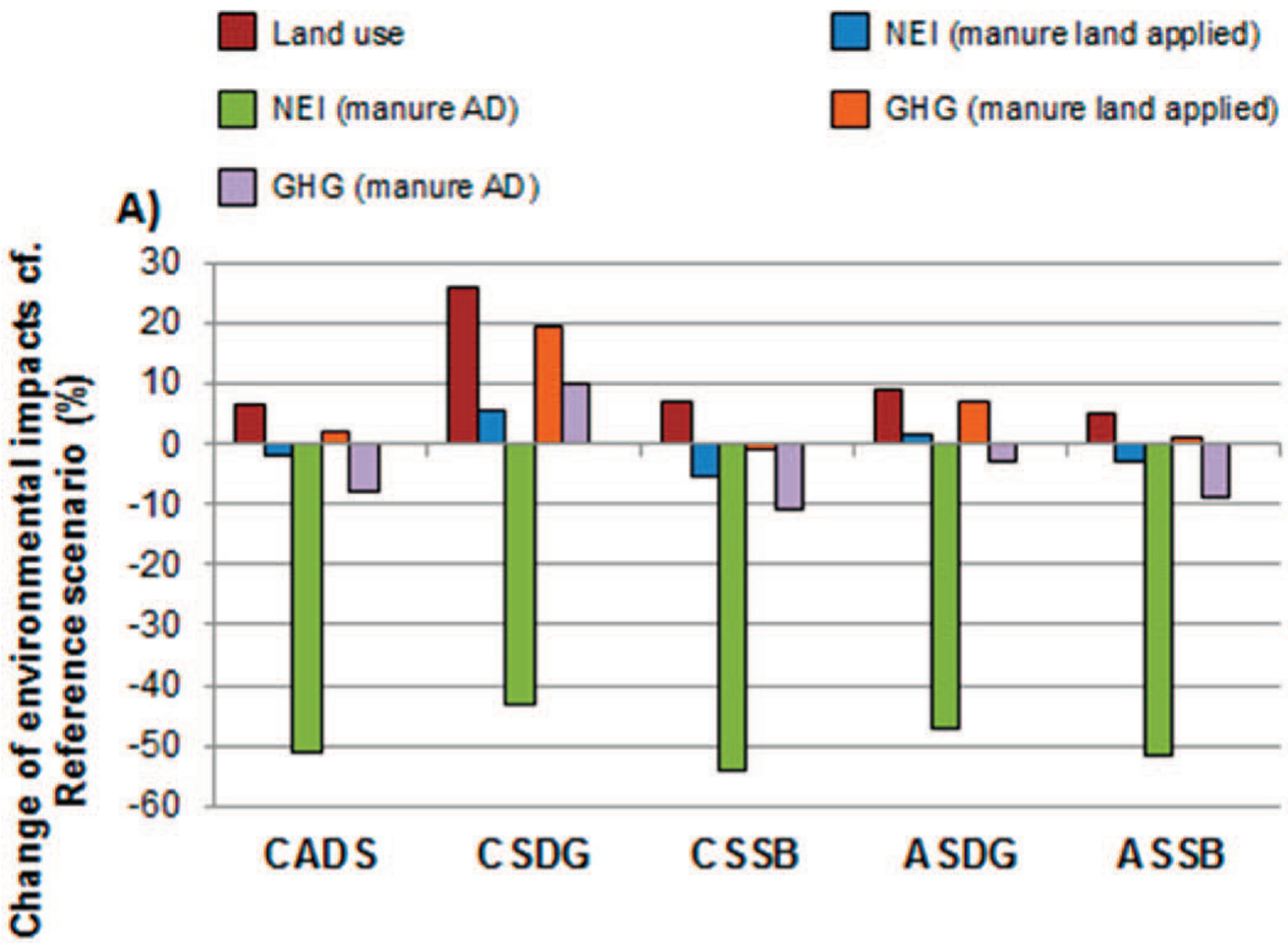

Land use

NEI (manure land applied)

NEI (manure AD)

GHG (manure land applied)

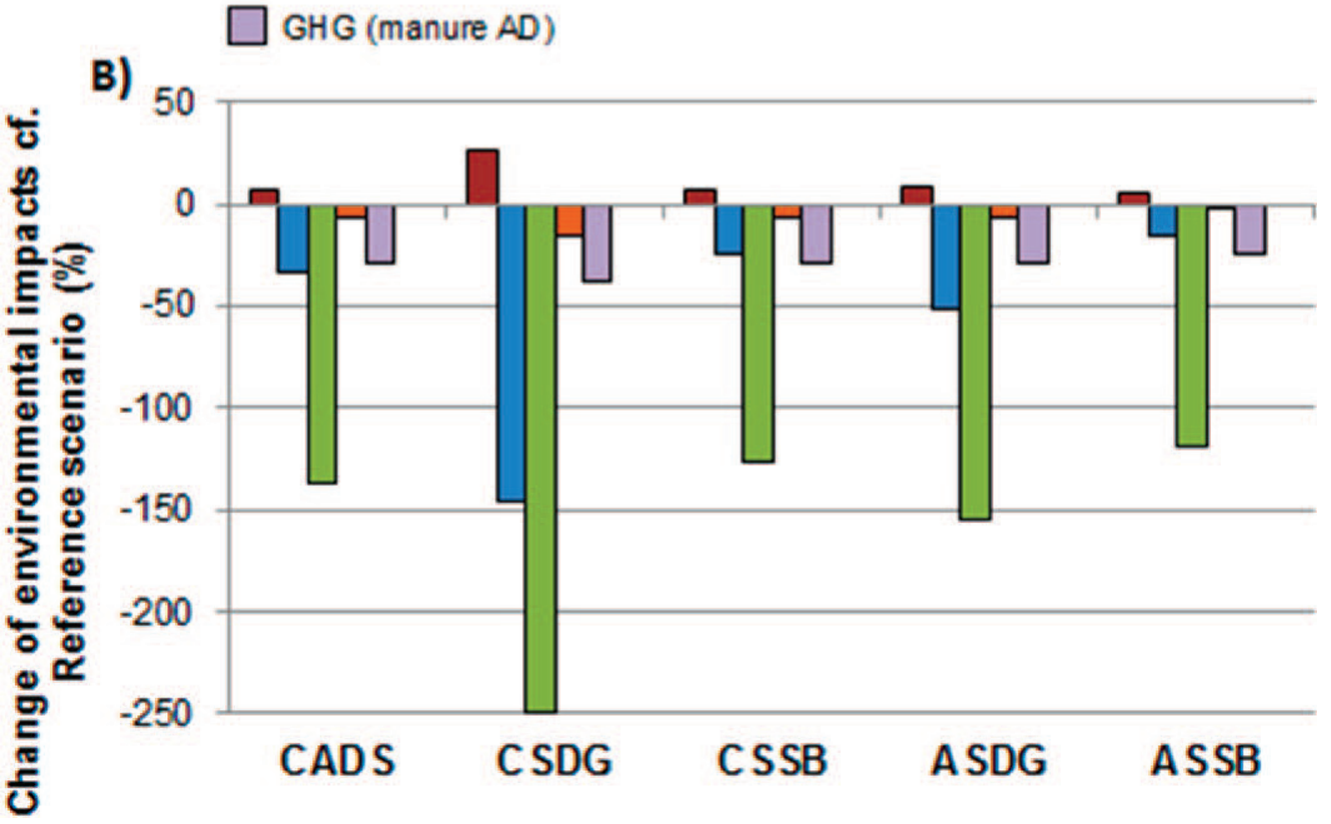

Figure 4. Marginal changes of land use, greenhouse gas (GHG) emissions, and net energy intensity (NEI) of each scenario of the integrated dairy and bioenergy system in relation to the reference system: (A) before allocating environmental effects to milk, (B) after allocating environmental effects to milk. Diet scenarios CADS, CSDG, CSSB, ASDG, and ASSB integrate the production of bioenergy into the system. Diet CADS has equal amounts of corn silage and alfalfa silage, and equal amounts of dry distillers grains with solubles (DDGS) and soybean meal (SBM). Diet CSDG has more corn silage than alfalfa silage and maximizes DDGS content. Diet CSSB has more corn silage than alfalfa silage and maximizes SBM content. Diet ASDG has more alfalfa silage than corn silage and maximizes DDGS content. Diet ASSB has more alfalfa silage than corn silage and maximizes SBM content; $\mathrm{AD}=$ anaerobic digestion. 
al., 2014). Fourth, carbon neutrality was assumed for biotic $\mathrm{CO}_{2}$ emissions, but previous studies suggest that the combustion of biodiesel from soybeans can increase $\mathrm{NO}_{\mathrm{x}}$ emissions by up to $15 \%$, which could reduce GHG credits by up to $4 \%$ (US EPA, 2002). In addition, it is assumed that biogas displaces the production and combustion of natural gas because it is the most similar primary fossil energy source. However, biogas is generally used to produce electricity in WI, which would affect both NEI due to lower conversion efficiencies and GHG credits given that electricity in WI comes mainly from coal.

Finally, the current paper applied a nutritional allocation approach to handle the multifunctionality between milk and meat. Different studies have shown that the choice of allocation strategy is highly influential on final results, economic allocation being one of the most applied strategies (Aguirre-Villegas et al., 2012; Mc Geough et al., 2012; O'Brien et al,. 2014). An economic relation can be determined based on the price of milk and meat. Milk prices depend on numerous factors that are related to the price of other dairy products (i.e., cheese, whey). A $\$ 0.6 / \mathrm{kg}$ of FPCM price of milk was calculated with formulas for Federal Order minimum prices (USDA-AMS, 2012) and based on average prices for WI cheese, whey, and other solids (USDA-NASS, 2014). In addition, $\$ 7.07 / \mathrm{kg}$ of meat was estimated based on meat spreadsheets from the USDA Economic Research Service (USDA-ERS, 2014). With daily production of $9,122 \mathrm{~kg}$ of FPCM and 29.5 $\mathrm{kg}$ of boneless meat by the modeled farm, this method would allocate $96 \%$ of the system inputs to milk and $4 \%$ to meat. Therefore, GHG emissions, NEI, and land use assigned to milk could be nearly $3 \%$ lower if this method is applied.

\section{CONCLUSIONS}

Land use, NEI, and GHG emissions of a reference dairy system representative of WI management practices were compared with a system that integrates dairy and bioenergy production. The effects of 5 different diets and 2 manure scenarios were evaluated in the integrated system. Diet scenarios that maximize DDGS content require the most land area, but are also the most effective in reducing GHG emissions and NEI, demonstrating the environmental trade-offs that need to be considered when analyzing different diet strategies. Reductions in GHG emissions and NEI come mainly from the credits of avoided emissions and primary energy from displaced fossil fuels after system expansion. Greenhouse gas emissions were further reduced by nearly $35 \%$ and NEI by $100 \%$ when implementing $\mathrm{AD}$ as a manure management practice. Overall, the integration of dairy and bioenergy production has the biggest influence on NEI when comparing marginal changes of environmental effects with respect to the reference system. The dairy industry will continue to dominate agricultural activities in WI for the foreseeable future and the emerging bioenergy industry will need to be integrated into existing agricultural systems. System models such as this one will help farmers and policy makers identify synergies between dairy production and renewable energy development. The system boundary expansion approach applied in this study reduces ambiguities produced by allocation decisions at the feedstock and co-product levels of integrated dairy and bioenergy systems, and provides a methodology for future studies.

\section{ACKNOWLEDGMENTS}

This study is part of the Green Cheese Project, funded by Wisconsin Focus on Energy, Environmental and Economic Research and Development Program (Madison, WI).

\section{REFERENCES}

AgSource. 2009. DHI Benchmarks Breed Averages. AgSource Cooperative Services. Accessed Feb. 20, 2014. http://agsource.crinet. com/scripts/benchmarks.php.

Aguirre-Villegas, H. A., R. A. Larson, and D. J. Reinemann. 2014. From waste-to-worth: Energy, emissions, and nutrient implications of manure processing pathways. Biofuels Bioprod. Biorefining 8:770-793. http://dx.doi.org/10.1002/bbb.1496.

Aguirre-Villegas, H. A., F. X. Milani, S. Kraatz, and D. J. Reinemann. 2012. Life cycle impact assessment and allocation methods development for cheese and whey processing. Trans. ASABE $55: 613-627$.

American Society of Agricultural and Biological Engineers (ASABE). 2005. Manure Production and Characteristics. ASAE D384.2 MAR2005. ASABE, St. Joseph, MI.

American Society of Agricultural and Biological Engineers (ASABE). 2006. Agricultural Machinery Management. Standards EP496.3. ASABE, St. Joseph, MI.

Amon, B., V. Kryvoruchko, T. Amon, and S. Zechmeister-Boltenstern. 2006. Methane, nitrous oxide and ammonia emissions during storage and after application of dairy cattle slurry and influence of slurry treatment. Agric. Ecosyst. Environ. 112:153-162. http:// dx.doi.org/10.1016/j.agee.2005.08.030.

Appels, L., J. Lauwers, J. Degrève, L. Helsen, B. Lievens, K. Willems, J. Van Impe, and R. Dewil. 2011. Anaerobic digestion in global bio-energy production: Potential and research challenges. Renew. Sustain. Energy Rev. 15:4295-4301. http://dx.doi.org/10.1016/j. rser.2011.07.121.

Avila, M., J. Posner, D. Laird, and P. Barak. 2005. Soil acidification processes in agroecosystems at Wisconsin Integrated Cropping System Trials (WISCST). In WISCST 10th Tech. Rep. Accessed Feb. 20, 2014. http://wicst.wisc.edu/technical-reports-peerreviewed-journal-articles/10th-technical-report-20032004/soil-acid ification-processes-in-agroecosystems-of-wicst/.

Azapagic, A., and R. Clift. 1999. Allocation of environmental burdens in multiple-function systems. J. Clean. Prod. 7:101-119.

Babcock, B. A., D. J. Hayes, and J. D. Lawrence. 2008. Using distillers grains in the U.S. and international livestock and poultry industries. Midwest Agribusiness Trade Research and Information Center. Accessed Feb. 20, 2014. http://www.card.iastate.edu/books/ distillers_grains/pdfs/distillers_grains_book.pdf. 
Beegle, D., K. Kelling, and M. Schmitt. 2008. Nitrogen from animal manures. Pages 823-882 in Nitrogen in Agricultural Systems. J. Schepers and W. Raun, ed. Agron. Mon. CSSA and SSSA, Madison, WI.

Bell, A. W., R. Slepetis, and U. A. Ehrhardt. 1995. Growth and accretion of energy and protein in the gravid uterus during late pregnancy in Holstein cows. J. Dairy Sci. 78:1954-1961.

Berglund, M., and P. Börjesson. 2006. Assessment of energy performance in the life-cycle of biogas production. Biomass Bioenergy 30:254-266. http://dx.doi.org/10.1016/j.biombioe.2005.11.011.

Boadi, D., C. Benchaar, J. Chiquette, and D. Massé. 2004. Mitigation strategies to reduce enteric methane emissions from dairy cows: Update review. Can. J. Anim. Sci. 84:319-335. http://dx.doi. org/10.4141/A03-109.

Bremer, V. R., A. J. Liska, T. J. Klopfenstein, G. E. Erickson, and H. S. Yang. 2010. Emissions savings in the corn-ethanol life cycle from feeding coproducts to livestock. J. Environ. Qual. 39:472-482. http://dx.doi.org/10.2134/jeq2009.0283.

Capper, J. L., R. Cady, and D. E. Bauman. 2009. The environmental impact of dairy production: 1944 compared with 2007. J. Anim. Sci. 87:2160-2167. http://dx.doi.org/10.2527/jas.2009-1781.

Cederberg, C., and M. Stadig. 2003. System expansion and allocation in life cycle assessment of milk and beef production. Int. J. Life Cycle Assess. 8:350-356.

Chianese, D. S., C. A. Rotz, and T. L. Richard. 2009. Simulation of methane emissions from dairy farms to assess greenhouse gas reduction strategies. Trans. ASABE 52:1313-1323.

CML. 2001. Handbook on Impact Categories "CML 2001". Institute of Environmental Sciences. Leiden University, Leiden, the Netherlands.

Curran, M. A. 2006. Life Cycle Assessment: Principles and Practice. United States Environmental Protection Agency (US EPA). Accessed Feb. 20, 2014. http://www.epa.gov/nrmrl/std/lca/lca.html.

De Vries, W., J. Kros, O. Oenema, and J. de Klein. 2003. Uncertainties in the fate of nitrogen II: a quantitative assessment of the uncertainties in major $\mathrm{N}$ fluxes in Netherlands. Nutr. Cycl. Agroecosystems 66:71-102.

del Prado, A., D. Chadwick, L. Cardenas, T. Misselbrook, D. Scholefield, and P. Merino. 2010. Exploring systems responses to mitigation of GHG in UK dairy farms. Agric. Ecosyst. Environ. 136:318-332. http://dx.doi.org/10.1016/j.agee.2009.09.015.

Del Rio, N. S., S. Stewart, P. Rapnicki, Y. M. Chang, and P. M. Fricke. 2007. An observational analysis of twin births, calf sex ratio, and calf mortality in Holstein dairy cattle. J. Dairy Sci. 90:1255-1264.

Ecoinvent Centre. 2007. Ecoinvent Data. v2.0. Ecoinvent Reports No.1-25. Accessed Mar. 15, 2014. www.ecoinvent.org.

Energy Center of Wisconsin (ECW). 2009. Efficiency and customer-sited renewable energy: Achievable potential in Wisconsin 2012-2018. In ECW Rep. Number 244-1. Accessed Feb. 20, 2014 https://psc.wi.gov/reports/documents/WIPotentialFinal.pdf.

Finnveden, G., M. Z. Hauschild, T. Ekvall, J. Guinée, R. Heijungs, S. Hellweg, A. Koehler, D. Pennington, and S. Sangwon. 2009. Recent developments in Life Cycle Assessment. J. Environ. Manage. 91:1-21. http://dx.doi.org/10.1016/j.jenvman.2009.06.018.

Foley, J. A., R. Defries, G. P. Asner, C. Barford, G. Bonan, S. R. Carpenter, F. S. Chapin, M. T. Coe, G. C. Daily, H. K. Gibbs, J. H. Helkowski, T. Holloway, E. A. Howard, C. J. Kucharik, C. Monfreda, J. A. Patz, I. C. Prentice, N. Ramankutty, and P. K. Snyder. 2005. Global consequences of land use. Science 309:570-574. http://dx.doi.org/10.1126/science.1111772.

Food and Agriculture Organization of the United Nations (FAO) 2000. The energy and agriculture nexus. Accessed Jan. 20, 2014 http://www.fao.org/uploads/media/EAN - final web-version.pdf.

Food and Agriculture Organization of the United Nations (FAO). 2010. Greenhouse gas emissions from the dairy sector-A life cycle assessment. Accessed Apr. 10, 2014. http://www.fao.org/ agriculture/lead/themes0/climate/emissions/en/.

Franco, D., E. Bispo, L. González, J. A. Vazquez, and T. Moreno. 2009. Effect of finishing and ageing time on quality attributes of loin from the meat of Holstein-Fresian cull cows. Meat Sci. 83:484-491. http://dx.doi.org/10.1016/j.meatsci.2009.06.030.
Goedkoop, M., R. Heijungs, M. Huijbregts, A. De Schryver, J. Struijs, and R. van Zelm. 2013. ReCiPe 2008. A life cycle assessment method which comprises harmonised category indicators at the midpoint and endpoing level. Accessed Aug. 15, 2014. http://www. lcia-recipe.net/file-cabinet.

Hadrich, J. C., T. M. Harrigan, and C. A. Wolf. 2010. Economic comparison of liquid manure transport and land application. Appl. Eng. Agric. 26:743-758.

Harper, L. A., T. K. Flesch, J. M. Powell, W. K. Coblentz, W. E. Jokela, and N. P. Martin. 2009. Ammonia emissions from dairy production in Wisconsin. J. Dairy Sci. 92:2326-2337. http:// dx.doi.org/10.3168/jds.2008-1753.

Hermans, J., D. J. Reinemann, L. E. Armentano, T. R. Fortenbery, and M. Wattiaux. 2006. Integrating bio-fuel production with Wisconsin dairy feed requirements. Proc. ASABE Int. Meet. Portland, Oregon. ASABE, St. Joseph, MI.

House, W. A., and A. W. Bell. 1993. Mineral accretion in the fetus and adnexa during late gestation in Holstein cows. J. Dairy Sci. 76:2999-3010.

Intergovernmental Panel on Climate Change (IPCC). 2006a. Chapter 11: $\mathrm{N} 2 \mathrm{O}$ emissions from managed soils, and $\mathrm{CO} 2$ emissions from lime and urea application. IPCC Guidel. Natl. Greenh. Gas Invent. Vol. 4 Agric. For. Other L. Use. Accessed Mar. 15, 2014. http:// www.ipcc-nggip.iges.or.jp/public/2006gl/pdf/4_Volume4/V4_11_ Ch11_N2O\&CO2.pdf.

Intergovernmental Panel on Climate Change (IPCC). 2006b. Chapter 10: Emissions from Livestock and Manure Management. IPCC Guide. Natl. Greenh. Gas Invent. Vol. 4 Agric. For. Other L. Use. Accessed Mar. 15, 2014. http://www.ipcc-nggip.iges.or.jp/ public/2006gl/pdf/4_Volume4/V4_10_Ch10_Livestock.pdf.

Intergovernmental Panel on Climate Change (IPCC). 2007. Climate Change 2007: Synthesis Report. Accessed Mar. 15 2014. http:// www.ipcc.ch/publications_and_data/publications_ipcc_fourth_ assessment_report_synthesis_report.htm.

International Dairy Federation (IDF). 2009. Environmental/Ecological Impact of the Dairy Sector: Literature review on dairy products for an inventory of key issues. Bulletin of the IDF 436/2009. International Dairy Federation, Brussels, Belgium.

International Dairy Federation (IDF). 2010. A common carbon footprint approach for dairy. The IDF guide to standard lifecycle assessment methodology for the dairy sector. Bulletin 445/2010. International Dairy Federation, Brussels, Belgium.

International Organization for Standardization (ISO). 2006. ISO 14040: Environmental management-Life cycle assessment-Principles and framework. ISO, Geneva, Switzerland.

Johnson, J. M.-F., A. J. Franzluebbers, S. L. Weyers, and D. C. Reicosky. 2007. Agricultural opportunities to mitigate greenhouse gas emissions. Environ. Pollut. 150:107-124. http://dx.doi. org/10.1016/j.envpol.2007.06.030.

Johnson, K. A., and D. Johnson. 1995. Methane emissions from cattle. J. Anim. Sci. 73:2483-2492.

Jokela, B., F. Magdoff, S. Barlett, S. Bosworth, and D. Ross. 2004. Nutrient recommendations for field crops in Vermont. Accessed Feb. 20 2014. http://pss.uvm.edu/vtcrops/?Page=nutrientmanure. html.

Jury, C., E. Benetto, D. Koster, B. Schmitt, and J. Welfring. 2010. Life cycle assessment of biogas production by monofermentation of energy crops and injection into the natural gas grid. Biomass Bioenergy 34:54-66. http://dx.doi.org/10.1016/j.biombioe.2009.09.011.

Kaufman, A. S., P. J. Meier, J. C. Sinistore, and D. J. Reinemann. 2010. Applying life-cycle assessment to low carbon fuel standardsHow allocation choices influence carbon intensity for renewable transportation fuels. Energy Policy 38:5229-5241. http://dx.doi. org/10.1016/j.enpol.2010.05.008.

Kim, S., and B. E. Dale. 2004. Cumulative energy and global warming impact from the production of biomass for biobased products. J. Ind. Ecol. 7:147-162.

Kim, S., and B. E. Dale. 2005. Life cycle assessment of various cropping systems utilized for producing biofuels: Bioethanol and biodiesel. Biomass Bioenergy 29:426-439. http://dx.doi.org/10.1016/j biombioe.2005.06.004. 
Kim, S., B. E. Dale, and R. Jenkings. 2009. Life cycle assessment of corn grain and corn stover in the United States. Int. J. Life Cycle Assess. 14:160-174.

Kraatz, S., D. J. Reinemann, and W. Berg. 2009. Energy inputs for corn production in Wisconsin and Germany. Appl. Eng. Agric. 25:653-662.

Laboski, C. A. M., and J. B. Peters. 2012. Nutrient application guidelines for field, vegetable, and fruit crops in WI (A2890). Accessed Feb. 20, 2014. http://learningstore.uwex.edu/assets/pdfs/A2809. pdf.

Lim, S., K. T. Lee, and P. Pinang. 2011. Parallel production of biodiesel and bioethanol in palm-oil-based biorefineries: life cycle assessment on the energy and greenhouse gases. Biofuels, Bioprod. Biorefining 5:132-150. http://dx.doi.org/10.1002/bbb.271

Martin, C., J. Rouel, J. P. Jouany, M. Doreau, and Y. Chilliard. 2008. Methane output and diet digestibility in response to feeding dairy cows crude linseed, extruded linseed, or linseed oil. J. Anim. Sci. 86:2642-2650. http://dx.doi.org/10.2527/jas.2007-0774.

Mc Geough, E. J., S. M. Little, H. H. Janzen, T. A. McAllister, S. M. McGinn, and K. A. Beauchemin. 2012. Life-cycle assessment of greenhouse gas emissions from dairy production in Eastern Canada: a case study. J. Dairy Sci. 95:5164-5175. http://dx.doi. org/10.3168/jds.2011-5229.

Meier Engineering Research (MER). 2011. MyPower electricity-sector model. MER LLC, Madison, WI.

Michel, J., A. Weiske, and K. Möller. 2010. The effect of biogas digestion on the environmental impact and energy balances in organic cropping systems using the life-cycle assessment methodology. Renew. Agric. Food Syst. 25:204-218. http://dx.doi.org/10.1017/ S1742170510000062.

Midwest Plan Service. 2000. Dairy Freestall Housing and Equipment. 7th ed. Iowa State University, Ames.

Minchin, W., F. Buckley, D. A. Kenny, F. J. Monahan, L. Shalloo, and M. O'Donovan. 2009. Effect of grass silage and concentrate based finishing strategies on cull dairy cow performance, carcass and meat quality characteristics. Meat Sci. 81:93-101. http://dx.doi. org/10.1016/j.meatsci.2008.07.001.

Moe, P., and H. Tyrrell. 1979. Methane production in dairy cows. J. Dairy Sci. 62:1583-1586.

Møller, H. B., S. G. Sommer, and B. K. Ahring. 2004. Methane productivity of manure, straw and solid fractions of manure. Biomass Bioenergy 26:485-495. http://dx.doi.org/10.1016/j.biombioe.2003.08.008.

Muñoz, I., G. Rigarlsford, L. M. Canals, and H. King. 2012. Accounting for greenhouse gas emissions from the degradation of chemicals in the environment. Int. J. Life Cycle Assess. 18:252-262. http:// dx.doi.org/10.1007/s11367-012-0453-4.

National Renewable Energy Laboratory (NREL). 2010. U.S. Life-Cycle Inventory (LCI) Database. http://www.nrel.gov/lci/about.html.

Nennich, T. D., J. H. Harrison, L. M. VanWieringen, D. Meyer, A J. Heinrichs, W. P. Weiss, N. R. St-Pierre, R. L. Kincaid, D. L. Davidson, and E. Block. 2005. Prediction of manure and nutrient excretion from dairy cattle. J. Dairy Sci. 88:3721-3733.

NRC. 2001. Nutrient Requirements of Dairy Cattle. 7th rev. ed. Natl. Acad Press, Washington, DC.

O'Brien, D. 2010. Measuring supply-use of distillers grains in the United States. Accessed Mar. 10, 2014. http://www.agmrc.org/ renewable_energy/ethanol/measuring-supply-use-of-distillersgrains-in-the-united-states/.

O'Brien, D., J. L. Capper, P. C. Garnsworthy, C. Grainger, and L. Shalloo. 2014. A case study of the carbon footprint of milk from high-performing confinement and grass-based dairy farms. J. Dairy Sci. 97:1835-1851. http://dx.doi.org/10.3168/jds.20137174

Patzek, T. 2004. Thermodynamics of the corn-ethanol biofuel cycle. Crit. Rev. Plant Sci. 23:519-567.

PE International. 2010. GaBi 4 Professional. Software and database for life cycle engineering.

Pimentel, D., and T. W. Patzek. 2005. Ethanol production using corn, switchgrass, and wood; biodiesel production using soy- bean and sunflower. Nat. Resour. Res. 14:65-76. http://dx.doi. org/10.1007/s11053-005-4679-8.

Poeschl, M., S. Ward, and P. Owende. 2012. Environmental impacts of biogas deployment-Part I: Life cycle inventory for evaluation of production process emissions to air. J. Clean. Prod. 24:168-183. http://dx.doi.org/10.1016/j.jclepro.2011.10.039.

Powell, J. M., G. A. Broderick, and T. H. Misselbrook. 2008. Seasonal diet affects ammonia emissions from tie-stall dairy barns. J. Dairy Sci. 91:857-869. http://dx.doi.org/10.3168/jds.2007-0588.

Pradhan, A., D. Shrestha, A. Mcaloon, W. Yee, M. Haas, J. A. Duffield, and H. Shapouri. 2011. Energy life-cycle assessment of soybean biodiesel revisited. Trans. ASABE 53:1031-1039.

PRe-sustainability. 2013. SimaPro Database Manual Methods Library. Accessed Aug. 15, 2014. http://simapro.de/uploads/media/ SimaPro8_Database-and-Methods-Manual.pdf.

Reap, J., F. Roman, S. Duncan, and B. Bras. 2008. A survey of unresolved problems in life cycle assessment: Part 1. Goal and scope and inventory analysis. Int. J. Life Cycle Assess. 13:290-300. http://dx.doi.org/10.1007/s11367-008-0008-x.

Rotz, C. A. M. S. Corson, D. S. Chianese, S. D. Hafner, R. Jarvis, and C. U. Coiner. 2011. The Integrated Farm System Model (IFSM) Reference Manual. Accessed Nov. 10, 2014 http://www.ars.usda. gov $/$ Main/docs.htm?docid $=8519$.

Rotz, C. A., F. Montes, and D. S. Chianese. 2010. The carbon footprint of dairy production systems through partial life cycle assessment. J. Dairy Sci. 93:1266-1282. http://dx.doi.org/10.3168/ jds.2009-2162.

Rotz, C. A., and J. Oenema. 2006. Predicting management effects on ammonia emissions from dairy and beef farms. Trans. ASABE 49:1139-1150.

Schuller, O., F. Hassel, M. Kokborg, D. Thylmann, A. Stoffregen, S Schöll, and M. Rudolf. 2013. GaBi database \& modelling principles 2013. Accessed Aug. 15, 2014. http://www.gabi-software.com/uploads/media/GaBi_Modelling_Principles_2013.pdf.

Schulte, E. E., L. M. Walsh, K. A. Kelling, L. G. Bundy, W. L. Bland, R. P. Wolkowski, J. B. Peters, and S. J. Sturgul. 2005. Management of Wisconsin Soils. Cooperative Extension, University of Wisconsin-Extension A3588. Madison, WI. Accessed Feb 10, 2014. http://learningstore.uwex.edu/Assets/pdfs/A3588.pdf.

Sheehan, J., V. Camobreco, J. Duffield, M. Graboski, and H. Shapouri 1998. Life cycle inventory of biodiesel and petroleum diesel for use in an urban bus. Accessed Aug. 15 2014. http://www.nrel.gov/ docs/legosti/fy98/24089.pdf.

Sinistore, J. 2008. Corn ethanol production in the Wisconsin agricultural context: Energy efficiency, greenhouse gas neutrality and soil and water implications. University of Wisconsin-Madison.

Stroade, J., A. Martin, and A. Conrad. 2009. Distillers grain industry: Production, use, structure and trends. Accessed Aug. 15, 2014. http://www.naiber.org/Publications/NAIBER/DistillersGrain-Industry.pdf.

Suh, S., B. Weidema, J. H. Schmidt, and R. Heijungs. 2010. Generalized make and use framework for allocation in life cycle assessment. J. Ind. Ecol. 14:335-353. http://dx.doi.org/10.1111/j.15309290.2010.00235.x.

Texas Agricultural Extension Service (TAES). 2000. Cotton potassium recommendation File K25. Texas A\&M AgriLife Extension Service, College Station.

Texas Agricultual Extension Service (TAES). 2001. Cotton nitrogen recommendation File N25. Texas A\&M AgriLife Extension Service, College Station.

Texas Agricultural Extension Service (TAES). 2006. Recommendation tables for oil crops. Texas A\&M AgriLife Extension Service, College Station.

Thoma, G., J. Popp, D. Nutter, D. Shonnard, R. Ulrich, M. Matlock, D. S. Kim, Z. Neiderman, N. Kemper, C. East, and F. Adom. 2013a. Greenhouse gas emissions from milk production and consumption in the United States: A cradle-to-grave life cycle assessment circa 2008. Int. Dairy J. 31:S3-S14. http://dx.doi org/10.1016/j.idairyj.2012.08.013.

Thoma, G., J. Popp, D. Shonnard, D. Nutter, M. Matlock, R. Ulrich, W. Kellogg, D. S. Kim, Z. Neiderman, N. Kemper, F. Adom, and 
C. East. 2013b. Regional analysis of greenhouse gas emissions from USA dairy farms: A cradle to farm-gate assessment of the American dairy industry circa 2008. Int. Dairy J. 31:S29-S40. http:// dx.doi.org/10.1016/j.idairyj.2012.09.010.

Thomassen, M. A., R. Dalgaard, R. Heijungs, and I. Boer. 2008. Attributional and consequential LCA of milk production. Int. J. Life Cycle Assess. 13:339-349. http://dx.doi.org/10.1007/s11367-0080007-y.

USDA Agricultural Marketing Service (USDA-AMS). 2012. Current price formulas. Accessed Oct. 17, 2014. http://www.ams.usda.gov/ AMSv1.0/PriceFormulas2012.

USDA Economic Research Service (USDA-ERS). 2001. Characteristics and production costs of U.S. cotton farms. Accessed Feb. 20, 2014. http://www.ers.usda.gov/publications/sb-statistical-bulletin/ sb-974-2.aspx\#.Uwp5qoUV-sk.

USDA Economic Research Service (USDA-ERS). 2014. Meat price spreads. Accessed Oct. 17, 2014. http://www.ers.usda.gov/ data-products/meat-price-spreads.aspx \#.VEGMc8mb3-t.

USDA National Agricultural Statistics Service (USDA-NASS). 2008. Agricultural chemical usage 2007. Field Crops Summary. Agricultural Statistics Board. Accessed Feb. 20, 2014. http://usda. mannlib.cornell.edu/usda/nass/AgriChemUsFC/2000s/2008/Agri ChemUsFC-05-21-2008.pdf.

USDA National Agricultural Statistics Service (USDA-NASS). 2009 Wisconsin agricultural statistics. WI-DATCP. Wisconsin Field Office. Wisconsin Department of Agriculture, Trade and Consumer Protection, Madison.

USDA National Agricultural Statistics Service (USDA-NASS). 2010. Texas reports and statistics. Texas Field Office and Texas Department of Agriculture, Austin.

USDA National Agricultural Statistics Service (USDA-NASS). 2013. Wisconsin agricultural statistics. Accessed Apr. 10, 2014. http:// www.nass.usda.gov/Statistics_by_State/Wisconsin/.

USDA National Agricultural Statistics Service (USDA-NASS). 2014. Wisconsin ag news-Milk prices. Accessed Oct. 17, 2014. http:// www.nass.usda.gov/Statistics_by_State/Wisconsin/Publications/ Dairy/2014/WI_MilkPrice09_14.pdf.

USDA National Resources Conservation Service (USDA-NRCS). 2009. Agricultural waste management field handbook. Accessed Sep. 3, 2014. http://www.nrcs.usda.gov/wps/portal/nrcs/detailfull/ national/water/?\&cid=stelprdb1045935.

USDA. 2007. Dairy 2007 Part I: Reference of Dairy Cattle Health and Management Practices in the United States. Colorado. Accessed Feb 20, 2014. http://www.aphis.usda.gov/animal_health/nahms/ dairy/downloads/dairy07/Dairy07_dr_PartI.pdf.

United States Environmental Protection Agency (US EPA). 2002. A comprehensive analysis of biodiesel impacts on exhaust emissions. Accessed Feb. 10, 2014. http://www.epa.gov/otaq/models/biodsl. htm.

Wang, M., H. Huo, and S. Arora. 2011. Methods of dealing with coproducts of biofuels in life-cycle analysis and consequent results within the U.S. context. Energy Policy 39:5726-5736. http:// dx.doi.org/10.1016/j.enpol.2010.03.052.

Wattiaux, M. A., and K. L. Karg. 2004. Protein level for alfalfa and corn silage-based diets: II. Nitrogen balance and manure characteristics. J. Dairy Sci. 87:3492-3502.

West, T., and G. Marland. 2002. A synthesis of carbon sequestration, carbon emissions, and net carbon flux in agriculture: comparing tillage practices in the United States. Agric. Ecosyst. Environ. 91:217-232.

Wheeler, E. F., M. A. Adviento-borbe, P. A. Topper, N. E. Brown, and G. Varga. 2008. Ammonia and greenhouse gas emissions from dairy freestall barn manure. ASABE Annu. Int. Meet. Providence, RI. ASABE, St. Joseph, MI.

Wilkerson, V. A., D. R. Mertens, and D. P. Casper. 1997. Prediction of excretion of manure and nitrogen by Holstein dairy cattle. J. Dairy Sci. 80:3193-3204.

WI Global Warming Task Force. 2008. Wisconsin's Strategy for Reducing Global Warming. Madison. Accessed Feb. 20, 2014. http:// psc.wi.gov/initiatives/globalWarming/documents/gwFinal.pdf.

\section{APPENDIX}

\section{Equations}

$$
\mathrm{N}_{\text {milk }}=\frac{\text { milk protein }}{6.38}+\mathrm{MUN}+(\text { milk yield } \times 0.203),
$$

from Wattiaux and Karg (2004), where $\mathrm{N}_{\text {milk }}=$ nitrogen in milk $(\mathrm{g})$, milk protein $=$ total protein in milk $(\mathrm{g})$, and $\mathrm{MUN}=$ milk urea $\mathrm{N}(\mathrm{g})=0.0148 \times \mathrm{N}$ intake $(\mathrm{g})+2.16$.

$$
\mathrm{N}_{\text {manure }}=\frac{(\mathrm{DMI} \times \text { dietary } \mathrm{CP} \times 78.39)+51.4}{1,000},
$$

from Nennich et al. (2005), where $\mathrm{N}_{\text {manure }}=$ nitrogen in manure (kg), DMI is in kilograms, and dietary $\mathrm{CP}$ is in grams per gram of DM.

$$
\mathrm{P}_{\text {milk }}=\frac{0.9 \times \text { milk }}{1,000}
$$

from NRC (2001), where $\mathrm{P}_{\text {milk }}=$ phosphorus in milk $(\mathrm{kg})$ and milk $=$ milk production $(\mathrm{kg})$.

$$
\mathrm{P}_{\text {manure }}=\frac{\mathrm{DMI} \times \text { dietary } \mathrm{P} \times 622.03}{1,000},
$$

from Nennich et al. (2005), where $\mathrm{P}_{\text {manure }}=$ phosphorus in manure $(\mathrm{kg})$, DMI is in kilograms, and dietary $\mathrm{P}$ is in grams per gram of DM).

$$
\mathrm{P}_{\text {fetus }}=0.01842 \times e^{[(0.05454-0.00007 \times 280) \times 280]},
$$

from House and Bell (1993), where $\mathrm{P}_{\text {fetus }}=$ phosphorus in fetuses $(\mathrm{kg})$ and $e=$ exponential.

$$
\mathrm{K}_{\text {milk }}=\frac{1.5 \times \text { milk }}{1,000}
$$

Table A1. Wisconsin electrical energy generation mix (MER, 2011)

\begin{tabular}{lc}
\hline $\begin{array}{l}\text { Electric } \\
\text { grid mix }\end{array}$ & $\begin{array}{c}\text { Electricity } \\
\text { delivered }(\%)\end{array}$ \\
\hline Coal & 54.7 \\
Natural gas & 18.6 \\
Nuclear & 20.7 \\
Hydro & 2.3 \\
Wind & 2.0 \\
Biomass/landfill gas & 1.5 \\
Solar & 0.2 \\
\hline
\end{tabular}




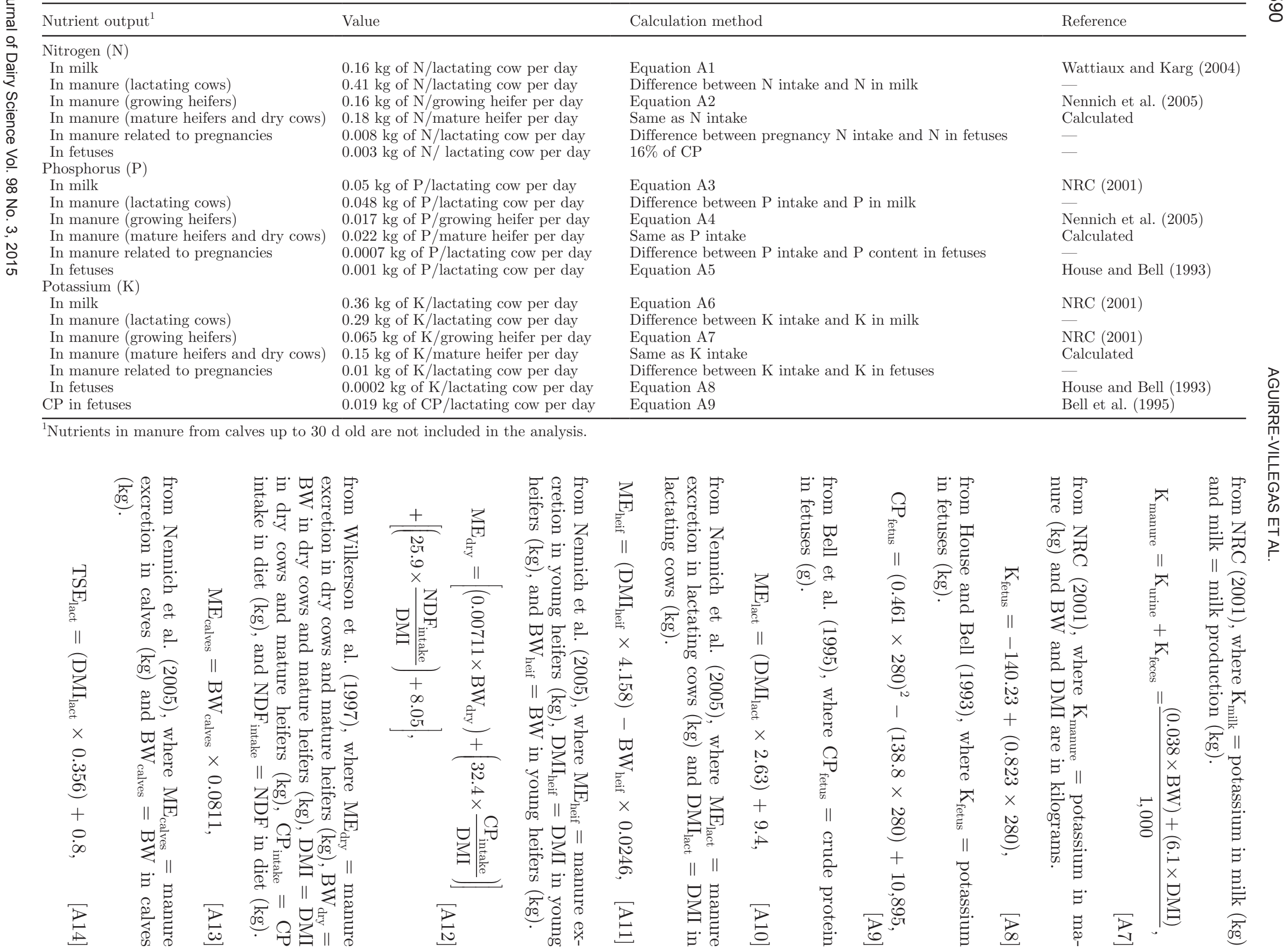


Table A3. Primary energy of inputs required for crops production

\begin{tabular}{lcl}
\hline Item & $\begin{array}{c}\text { Primary } \\
\text { energy }\end{array}$ & Reference \\
\hline $\mathrm{N} \mathrm{fertilizer}^{1}$ & $41.2 \mathrm{MJ} / \mathrm{kg}$ & NREL $(2010)$ \\
$\mathrm{P}$ fertilizer $^{1}$ & $6.38 \mathrm{MJ} / \mathrm{kg}$ & NREL $(2010)$ \\
K fertilizer $^{1}$ & $6.13 \mathrm{MJ} / \mathrm{kg}$ & PE International $(2010)$ \\
Herbicides $^{2}$ & West and Marland (2002) \\
Pesticides & $232 \mathrm{MJ} / \mathrm{kg}$ & PE International $(2010)$ \\
Agricultural lime & $1.47 \mathrm{MJ} / \mathrm{kg}$ & Kim and Dale $(2004)$ \\
Diesel & $46.1 \mathrm{MJ} / \mathrm{L}$ & PE International $(2010)$ \\
Gasoline & $41.2 \mathrm{MJ} / \mathrm{L}$ & PE International $(2010)$ \\
Liquefied petroleum gas & $28.8 \mathrm{MJ} / \mathrm{L}$ & PE International $(2010)$ \\
Oil & $63.85 \mathrm{MJ} / \mathrm{L}$ & PE International $(2010)$ \\
Electricity & $11.0 \mathrm{MJ} / \mathrm{kWh}^{2}$ & NREL $(2010)$ \\
Natural gas & $42.3 \mathrm{MJ} / \mathrm{m}^{2}$ & PE International $(2010)$ \\
Machinery manufacture & $45.9 \mathrm{MJ} / \mathrm{kg}^{3}$ & Patzek (2004) \\
Corn ethanol & $20 \mathrm{MJ} / \mathrm{L}^{3}$ & Pimentel and Patzek $(2005)$ \\
Soy biodiesel & $17.1 \mathrm{MJ} / \mathrm{kg}^{2}$ & Pimentel and Patzek $(2005)$ \\
\hline
\end{tabular}

${ }^{1}$ The primary energy for purchased fertilizers (not including manure) is presented for nitrogen (N), phosphorus $(\mathrm{P})$ and potassium $(\mathrm{K})$

${ }^{2}$ Assuming $4,078 \mathrm{kcal} / \mathrm{kg}$ of biodiesel from soybeans (including energy related to electricity, steam, cleanup water, space heat, direct heat, losses, stainless steel, steel, and cement).

${ }^{3}$ Assuming 4,075 kcal/L of ethanol from corn (including energy related to corn transport, water, stainless steel, steel, cement, steam, electricity, distillation from $95 \%$ ethanol to $99 \%$, and sewage effluent).

from Nennich et al. (2005), where $\mathrm{TS}_{\text {elact }}=$ total solids excreted in lactating cows $(\mathrm{kg})$ and $\mathrm{DMI}_{\text {lact }}=\mathrm{DMI}$ in lactating cows $(\mathrm{kg})$.

$$
\mathrm{TSE}_{\mathrm{dry}}=(\mathrm{DMI} \times 0.178)+2.733,
$$

from ASABE (2005), where $\mathrm{TSE}_{\text {dry }}=$ total solids excreted by dry cows and mature heifers $(\mathrm{kg})$ and DMI $=$ DMI in dry cows and mature heifers $(\mathrm{kg})$.

$$
\begin{gathered}
\text { Enteric } \mathrm{CH}_{4}=0.814+(0.122 \times \text { soluble residue }) \\
+(0.415 \times \text { hemicellulose })+(0.633 \times \text { cellulose }),[\text { A16 }]
\end{gathered}
$$

from Moe and Tyrrell (1979), where Enteric $\mathrm{CH}_{4}=$ methane emissions due to enteric fermentation (Mcal).

$$
\begin{gathered}
\mathrm{CH}_{4 \text { application }}=\left[\left(0.17 \times \mathrm{F}_{\mathrm{VFA}}\right)+0.026\right] \\
\times \mathrm{A}_{\text {crop }} \times 0.032,
\end{gathered}
$$

from Chianese et al. (2009), where $\mathrm{CH}_{4}$ application $=$ methane daily emissions ( $\mathrm{kg}$ of $\left.\mathrm{CH}_{4} / \mathrm{d}\right), \mathrm{F}_{\mathrm{VFA}}=$ daily concentration of VFA in manure ( $\mathrm{mmol} / \mathrm{kg}$ of manure); $\mathrm{F}_{\mathrm{VFA}}=\mathrm{F}_{\mathrm{VFA}}$ initial $\times e^{-0.6939 \times t}$, where $\mathrm{F}_{\mathrm{VFA} \text { initial }}=$ initial concentration of VFA in manure when applied (mmol/ $\mathrm{kg}$ of manure), and $t=$ time since application (days, $t$ $=0$ when manure is applied $) ;=\left(\mathrm{F}_{\mathrm{TAN}} / 2.02\right) \times(9.43-$ $\mathrm{pH})$, where $\mathrm{F}_{\mathrm{TAN}}=$ concentration of total ammonia $\mathrm{N}$ in manure $\left(\mathrm{mmol} / \mathrm{kg}\right.$ of manure), and $\mathrm{A}_{\text {crop }}=$ area of land where manure is applied (Ha).

$$
\mathrm{CH}_{4 \text { barn floor }}=\max (0,0.13 \times T) \times \frac{\mathrm{A}_{\text {barn }}}{1,000},
$$

from Chianese et al. (2009), where $\mathrm{CH}_{4}$ barn floor $=$ daily rate of $\mathrm{CH}_{4}$ emissions from the barn $\left(\mathrm{kg}\right.$ of $\left.\mathrm{CH}_{4} / \mathrm{d}\right)$, $\max =$ maximum value, $T=$ temperature, and $\mathrm{A}_{\text {barn }}=$ area of the barn exposed to manure.

$$
\begin{aligned}
& \mathrm{CH}_{4 \text { storage }}=\left[\left(\frac{24 \times \mathrm{VS}_{\mathrm{d}} \times b_{1}}{1,000}\right) \times e^{\left(\ln (A)-\frac{E}{R T}\right)}\right] \\
& +\left[\left(\frac{24 \times \mathrm{VS}_{\mathrm{nd}} \times b_{2}}{1,000}\right) \times e^{\left(\ln (A)-\frac{E}{R T}\right)}\right],
\end{aligned}
$$

from Chianese et al. (2009), where $\mathrm{CH}_{4 \text { storage }}=$ daily emissions of methane ( $\mathrm{g}$ of $\left.\mathrm{CH}_{4} / \mathrm{d}\right), \mathrm{VS}_{\mathrm{d}}=$ degradable VS in manure $(\mathrm{g}), \mathrm{VS}_{\mathrm{nd}}=$ nondegradable VS in manure $(\mathrm{g}), b_{1}$ and $b_{2}=$ rate-correcting factors $\left(b_{1}=1, b_{2}=\right.$

Table A4. Energy densities of the fuels used in the system

\begin{tabular}{lcrc}
\hline Fuel & $\mathrm{kg}$ & \multicolumn{1}{c}{$\mathrm{L}$} & $\mathrm{MJ}$ \\
\hline Methane & 0.68 & 1,000 & 37.8 \\
Gasoline & 0.74 & 1 & 34.7 \\
Liquefied petroleum gas & 0.54 & 1 & 26.9 \\
Natural gas & 0.88 & 1,000 & 38.2 \\
Corn ethanol & 0.79 & 1 & $21.5^{1}$ \\
Soy biodiesel & 0.88 & 1 & $33.2^{1}$ \\
Petro-diesel & 0.84 & 1 & 38.4 \\
\hline
\end{tabular}

${ }^{1}$ Assuming $5,130 \mathrm{kcal} / \mathrm{L}$ of ethanol and $9,000 \mathrm{kcal} / \mathrm{kg}$ of biodiesel (Pimentel and Patzek, 2005). 
Table A5. Potential acidification rate of crops and lime requirements to supply calcium removal in harvested material and to neutralize acidification rate

\begin{tabular}{|c|c|c|c|c|}
\hline Item & Alfalfa & $\begin{array}{c}\text { Corn } \\
\text { for silage }\end{array}$ & $\begin{array}{c}\text { Corn } \\
\text { for grain }\end{array}$ & Soybean \\
\hline Acidification $\operatorname{rate}^{1}\left(\mathrm{kmol}\right.$ of $\left.\mathrm{H}^{+} / \mathrm{ha}\right)$ & 14.5 & 4.5 & 0.8 & 3.3 \\
\hline Lime required to supply calcium removal ${ }^{2}\left(\mathrm{~g}\right.$ of $\mathrm{CaCO}_{3} / \mathrm{kg}$ of $\mathrm{DM}$ ) & 64 & 13 & 2 & 35 \\
\hline
\end{tabular}

${ }^{1}$ From Avila et al. (2005).

${ }^{2}$ Calculated based on Schulte et al. (2005).

${ }^{3}$ Assuming $50 \mathrm{~g}$ of $\mathrm{CaCO}_{3} / \mathrm{kmol}$ of $\mathrm{H}^{+}$(Avila et al., 2005).

0.01, dimensionless), $A=$ Arrhenius parameter ( $\mathrm{g}$ of $\mathrm{CH}_{4} / \mathrm{kg}$ of VS per hour), $\ln (A)=43.33, E=$ apparent activation energy $(112,700 \mathrm{~J} / \mathrm{mol}), R=$ gas constant (8.314 J/K per mol), and $T=$ temperature $(\mathrm{K})$.

$\mathrm{NH}_{3 \text { application }}=\frac{\operatorname{TAN} \times\left[(20+5 \times \mathrm{TS}) \times\left(\frac{\text { days }}{\text { days }+0.3}\right)\right] \times\left(\frac{17}{14}\right)}{100}$, [A20] from Jokela et al. (2004), where $\mathrm{NH}_{3}$ application $=$ total ammonia emissions after application $\left(\mathrm{kg}\right.$ of $\left.\mathrm{NH}_{3}\right)$, TAN $=$ total ammonia nitrogen in manure $\left(\mathrm{kg}\right.$ of $\left.\mathrm{NH}_{3}-\mathrm{N}\right)$, $\mathrm{TS}=\mathrm{TS}$ in applied manure (\%), and days $=$ number of days it takes to incorporate manure (if not incorporated, days $>7$ ). 